Article

\title{
Occurrence of Felsic Rocks in Oceanic Gabbros from IODP Hole U1473A: Implications for Evolved Melt Migration in the Lower Oceanic Crust
}

\author{
Du Khac Nguyen ${ }^{1,2, *}$, Tomoaki Morishita ${ }^{3, *}$, Yusuke Soda ${ }^{3}$, Akihiro Tamura ${ }^{3}$,
} Biswajit Ghosh ${ }^{4}$, Yumiko Harigane ${ }^{5}$, Lydéric France ${ }^{6}$, Chuanzhou Liu ${ }^{7}$, James H. Natland ${ }^{8}$, Alessio Sanfilippo ${ }^{9}$, Christopher J. MacLeod ${ }^{10}{ }^{\circ}$, Peter Blum ${ }^{11}$ and Henry J. B. Dick ${ }^{12}$

1 Graduate School of Natural Science and Technology, Kanazawa University, Kakuma-machi, Kanazawa Ishikawa 920-1192, Japan

2 Faculty of Geosciences and Geoengineering, Hanoi University of Mining and Geology, Hanoi 100000, Vietnam

3 College of Science and Engineering, Kanazawa University, Kakuma-machi, Kanazawa Ishikawa 920-1192, Japan; nahco3soda@gmail.com (Y.S.); aking826@gmail.com (A.T.)

4 Department of Geology, University of Calcutta, 35 Ballygunge Circular Road Kolkata, West Bengal 700019, India; bghosh_geol@hotmail.com

5 Institute of Geology and Geoinformation, Geological Survey of Japan, National Institute of Advanced Industrial Science and Technology, AIST Tsukuba Central 7, 1-1-1 Higashi, Tsukuba Ibaraki 305-8567, Japan; y-harigane@aist.go.jp

6 Centre de Recherches Pétrographiques et Géochimiques (UMR 7358), CNRS, Université de Lorraine, 54501 Vandœuvre les Nancy, France; lyde@crpg.cnrs-nancy.fr

7 State Key Laboratory of Lithospheric Evolution, Institute of Geology and Geophysics, Chinese Academy of Sciences, P.O. Box 9825, Beijing 100029, China; chzliu@mail.iggcas.ac.cn

8 Rosenstiel School of Marine and Atmospheric Science, University of Miami, Miami, FL 33156, USA; jnatland@rsmas.miami.edu

9 Department of Earth Science and Environment, University of Pavia, 27100 Pavia, Italy; spessio84@gmail.com

10 School of Earth and Ocean Sciences, Cardiff University, Main Building, Park Place Cardiff, Wales CF10 3AT, UK; macleod@cardiff.ac.uk

11 International Ocean Discovery Program, Texas A\&M University, 1000 Discovery Drive, College Station, TX 77845-9547, USA; blum@iodp.tamu.edu

12 Department of Geology and Geophysics, Woods Hole Oceanographic Institution, MS \#8, McLean Laboratory, Woods Hole, MA 02543-1539, USA; hdick@whoi.edu

* Correspondences: nguyenkhacdu@humg.edu.vn (D.K.N.); moripta@se.kanazawa-u.ac.jp (T.M.); Tel.: +81-080-5858-9686 (D.K.N.); +81-080-9808-5314 (T.M.)

Received: 12 October 2018; Accepted: 7 December 2018; Published: 10 December 2018

\begin{abstract}
Felsic rocks are minor in abundance but occur ubiquitously in International Ocean Discovery Program Hole U1473A, Southwest Indian Ridge. The trace element abundances of high-Ti brown amphibole, plagioclase, and zircon in veins, as well as the presence of myrmekitic texture in the studied felsic rocks support crystallization origin from highly-evolved melts, probably controlled by fractional crystallization. Based on geochemical criteria and texture of the mineral assemblage in felsic rocks and their relationship with host gabbros, they can be divided into three types: (1) Felsic rock with sharp boundaries is formed when felsic melt intrudes into fractures of host gabbros, resulting in minimal interaction between the melt and the wall minerals. (2) Replacive felsic rock, which is characterized by a pseudomorphic replacement of minerals in the host gabbro. This vein type is caused by the replacement of the host mineralogy by minerals in equilibrium with the felsic melts. (3) Felsic rock with diffused boundaries is formed either by infiltration of felsic melt into the solidifying gabbro body or crystallization of interstitial melts. Infiltration modes of felsic melts are likely controlled by the temperature condition of the cooling host gabbros.
\end{abstract}


Keywords: IODP; hole U1473A; Atlantis Bank; gabbros; felsic veins; melt-rock interactions; oceanic plagiogranite

\section{Introduction}

The lower oceanic crust is dominated by gabbroic sequences with compositions ranging from troctolite, olivine gabbro to evolved oxide gabbros. The formation of the lower crust is generally believed to be an integrated process from generation to crystallization of basaltic magmas derived from partial melting of adiabatically upwelled asthenospheric mantle at the mid-ocean ridge.

It has been, however, documented that reaction between the gabbroic mineral assemblage in the earlier stages of crystallization and migrating melts is an important process in melt evolution beneath mid-ocean ridge [1-3]. Lissenberg and his colleagues [4] pointed out that reactive porous flow exhibits at both grain and sample scales, which changes original lithology to another one, such as troctolite to olivine gabbro.

Hole U1473A, drilled on the summit of Atlantis Bank, Southwest Indian Ridge during International Ocean Discovery Program (IODP) Expedition 360 provides an excellent opportunity to study more about the lower oceanic crust at ultra-slow spreading ridges. Felsic rocks observed in Hole U1473A are primarily distinguished by their typical whitish color and igneous textures. Based on the visual estimation of drilled cores, felsic rocks are minor (about 1.5 vol.\%) but ubiquitous throughout the hole [5]. The origin of melts forming felsic rocks in oceanic crust is diverse and is still debated. The felsic rocks are generally interpreted to have formed either from highly evolved fractionated melts in the late stage of crystallization of the gabbroic sequences, or by partial melting of pre-existing hydrothermally altered crustal rocks [6-17]. The intimate association of felsic rocks and oxide gabbros in slow-spreading ridge samples suggests another mechanism for the formation of the felsic melt, such as liquid immiscibility, as discussed and experimentally proved in References [18-21] and references therein. Whereas, at fast-spreading centers, Zhang and his colleagues in Reference [9] argued that felsic melt could also be derived from hydrous low-degree melting of the sheeted dike complexes.

In this study, based on petrographic observations and mineral chemistry, we present the diverse occurrences of felsic rocks in the host gabbros of Hole U1473A. We propose the most suitable model among the existing ones for the formation of studied felsic rocks in Hole U1473A. Finally, we discuss various infiltration modes of evolved melts forming the felsic rocks corresponding to their appearances and boundary relationships with the host gabbro.

\section{Materials and Methods}

\subsection{Geological Background and Lithology of Hole U1473A}

Hole U1473A $\left(32^{\circ} 42.3622^{\prime}\right.$ S; $\left.057^{\circ} 16.6880^{\prime} \mathrm{E}\right)$, located on the summit of Atlantis Bank at the Southwest Indian Ridge was drilled to $789.7 \mathrm{~m}$ below seafloor (mbsf) during IODP Exp. 360 into massive gabbros that are locally cut by isolated dikes (Figure 1). This oceanic crust formed $\sim 11 \mathrm{Ma}$ ago beneath the ultra-slow Southwest Indian Ridge with a full-spreading rate of $14 \mathrm{~mm} /$ year $[11,22]$. Previous Ocean Drilling Program (ODP) operations drilled two other holes at Atlantis Bank, located at $1-2 \mathrm{~km}$ from the Hole U1473A. These include Hole $735 \mathrm{~B}\left(32^{\circ} 43.39^{\prime} \mathrm{S}, 57^{\circ} 15.96^{\prime} \mathrm{E}, 1508 \mathrm{~m}\right.$ deep) drilled during ODP Leg 118 in 1987 and ODP Leg 176 in 1997 and Hole 1105A $\left(32^{\circ} 43.13^{\prime}\right.$ S, 57 $7^{\circ} 16.65^{\prime}$ E, $158 \mathrm{~m}$ deep) drilled during ODP Leg 179 in 1998. Both holes recovered long sections of gabbros, consisting largely of olivine gabbros, followed by subordinate amounts of oxide (-bearing) gabbros, minor troctolite and leucocratic veins [11,23-25].

The most abundant rock type of the gabbros recovered from Hole U1473A is olivine gabbro (containing $<1 \%$ oxide; 76.5 vol. $\%$ ); followed by significant proportions of disseminated-oxide gabbro (1-2\% oxide; 9.5 vol.\%) and gabbro (<1\% oxide; 5.1 vol.\%), oxide gabbro (>5\% oxide; 3.7 vol. \%), 
oxide bearing gabbro (2-5\% oxide; 3.7 vol. \%) [5]. The relationships between these rock types are very complex and vary from: (1) simple interlocking igneous contacts between undeformed gabbros with subparallel coarse- to pegmatitic-oxide gabbro layers; (2) isolated patches of oxide- and pyroxene-rich gabbro intercalated with the olivine gabbro; (3) oxide concentrations that indicate local migration of late Fe-Ti oxide-rich melts along active shear zones. The Fe-Ti-rich oxide gabbro and gabbronorite occurrences, whether in layers and patches or within shear zones, appear to have crystallized from evolved interstitial melt compacted out of the olivine gabbro cumulates, and record the migration of these melts through the section.

Felsic rocks selected for the present study encompass whitish igneous veins, blobs, and networks, making an account for a small amount, approximately 1.5 vol. $\%$ of the entire section.

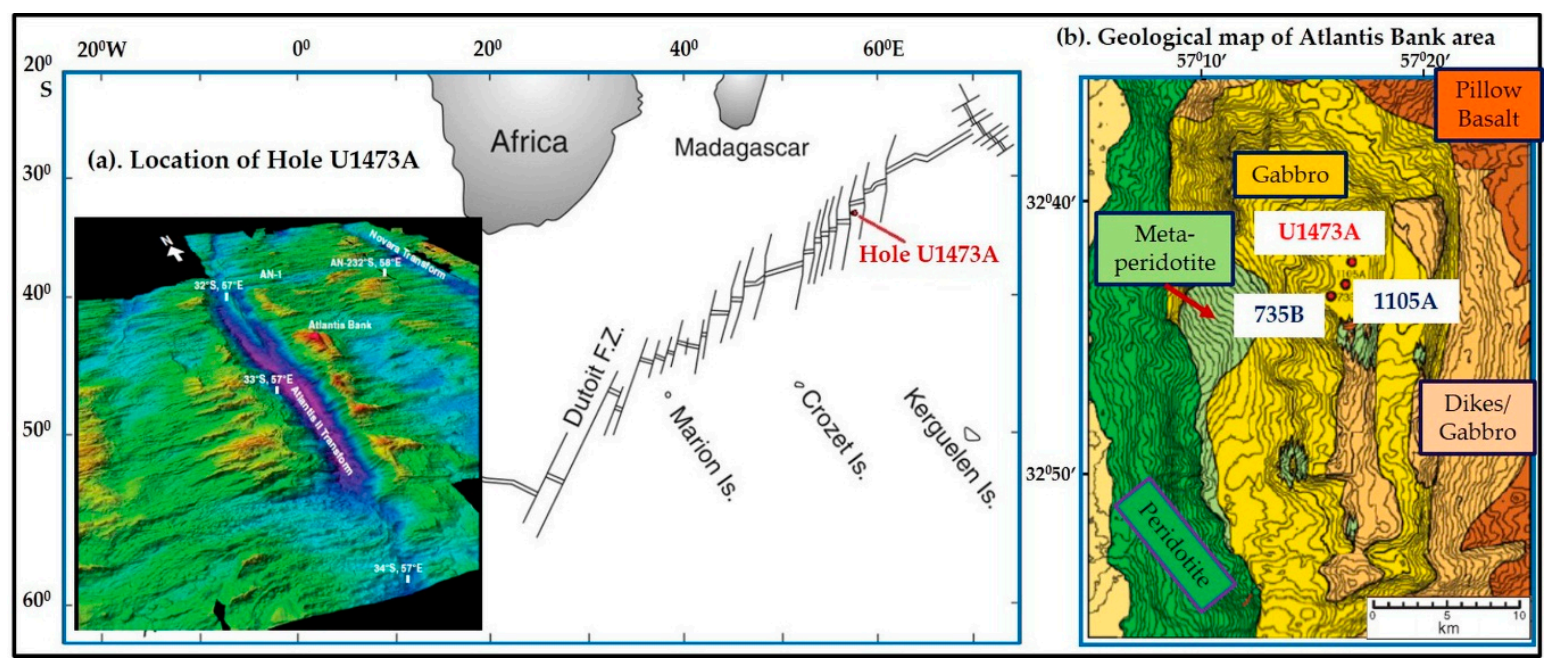

Figure 1. (a) Location of Hole U1473A and 3D view of the Atlantis Bank; (b) Summary of geological mapping with Ocean Drilling Program/International Ocean Discovery Program (ODP/IODP) drill sites marked and geological interpretation based on site survey results, modified from References $[6,26]$.

\subsection{General Description of Host Gabbros and Felsic Veins}

Petrographic descriptions and mineral mode calculations were carried out through combined results of observations under the optical microscope, enlarged photos taken by scanning thin sections with/without polarized plates, and X-ray elemental mapping images.

Felsic rocks are present in all lithologies, i.e., olivine gabbro, gabbro, oxide (-bearing) (olivine) gabbro (norite). The various modes of interaction between felsic rocks and host gabbros are described in detail based on seven samples including the host olivine gabbros $(n=4)$, gabbros $(n=2)$, and oxide-bearing gabbro $(n=1)$. In order to track melt migration and melt-rock interactions in the crystallizing lower crust where the effect of deformation is minimum, we have focused on the least deformed samples. Although quantifying the effect of deformation on melt migration is of great interest in understanding the origin of oceanic crust, but this aspect is beyond the scope of the present study. The summary of observations of the studied samples is presented in Tables 1-3. 
Table 1. Detailed characteristics of studied host gabbros samples-Hole U1473A.

\begin{tabular}{|c|c|c|c|c|c|c|c|c|c|c|}
\hline \multirow[b]{2}{*}{ No } & \multirow{2}{*}{$\begin{array}{l}\text { Leg 360-Hole } \\
\text { U1473A-Sample }\end{array}$} & \multirow{2}{*}{$\begin{array}{l}\text { Depth } \\
\text { (mbsf) }\end{array}$} & \multirow[b]{2}{*}{ Vol (\%) } & \multirow{2}{*}{$\begin{array}{l}\text { Domain } \\
\text { Lithology }\end{array}$} & \multirow[b]{2}{*}{ General Comments } & \multicolumn{5}{|c|}{ Host Gabbros—Mineral Mode (\%) } \\
\hline & & & & & & $\begin{array}{l}\text { Plagioclase Modal; An } \\
\text { Mean (Range); N }\end{array}$ & $\begin{array}{l}\text { Clinopyroxene Modal; } \\
\text { Mg\# Mean (Range); }\end{array}$ & $\begin{array}{l}\text { Olivine Modal; Fo } \\
\text { Mean (Range); N } \\
\end{array}$ & Ortho-pyroxene & Fe-Ti Oxide \\
\hline 1 & $41 \mathrm{R} 2,26-31 \mathrm{~cm}$ & 373.11 & 20 & $\begin{array}{l}\text { Olivine } \\
\text { gabbro }\end{array}$ & $\begin{array}{c}\text { Coarse grained; } \\
\text { strongly altered; } \\
\text { Host of felsic Vein-S }\end{array}$ & $\begin{array}{l}\text { 43; Core: } 53 \text { (52-54); } 4 \\
\text { Rim: } 53 \text { (52-53); } 4\end{array}$ & $\begin{array}{l}\text { 50; Core: } 86 \text { (83-90); } 5 \\
\text { Rim: } 86 \text { (85-88); } 4\end{array}$ & 7; completely altered & - & $<1$ \\
\hline 2 & $64 \mathrm{R} 2,110-113 \mathrm{~cm}$ & 578.78 & 20 & Gabbro & $\begin{array}{l}\text { Medium grained; } \\
\text { moderately altered; } \\
\text { Host of felsic Vein-S }\end{array}$ & 60 ; Core: 55 (54-56); 4 & $\begin{array}{l}\text { 40; Core: } 80 \text { (76-84); } 6 \\
\text { Rim: } 81(80-83) ; 5\end{array}$ & - & $<1$ & $\mathrm{~T}$ \\
\hline 3 & $64 \mathrm{R} 2,128-133 \mathrm{~cm}$ & 578.96 & 70 & $\begin{array}{l}\text { Olivine } \\
\text { gabbro }\end{array}$ & $\begin{array}{l}\text { Medium grained; } \\
\text { strongly altered; } \\
\text { Host of felsic Vein-S }\end{array}$ & $\begin{array}{l}\text { 47; Core: } 57 \text { (53-59); } 20 \\
\text { Rim: } 57 \text { (53-59); } 20\end{array}$ & $\begin{array}{l}\text { 35; Core: } 82 \text { (76-87); } 33 \\
\text { Rim: } 82 \text { (76-85); } 19\end{array}$ & $\begin{array}{l}\text { 18; Core: } 74(72-75) ; 16 \\
\text { Rim: } 74 \text { (73-75); } 13\end{array}$ & $<1$ & $<1$ \\
\hline 4 & $66 \mathrm{R} 4,46-49 \mathrm{~cm}$ & 601.82 & 55 & Gabbro & $\begin{array}{l}\text { Pegmatitic grained; } \\
\text { strongly altered; } \\
\text { Host of felsic Vein-R }\end{array}$ & $\begin{array}{l}\text { 70; Core: } 57 \text { (54-62); } 25 \\
\text { Rim: } 57 \text { (54-61); } 18\end{array}$ & $\begin{array}{l}\text { 30; Core: } 85 \text { (84-88); } 7 \\
\text { Rim: } 86 \text { (84-88); } 6\end{array}$ & - & - & $\mathrm{T}$ \\
\hline 5 & $66 \mathrm{R} 5,1-7 \mathrm{~cm}$ & 602.83 & 80 & $\begin{array}{l}\text { Olivine } \\
\text { gabbro }\end{array}$ & $\begin{array}{l}\text { Medium grained; } \\
\text { strongly altered; } \\
\text { Host of felsic Vein-R }\end{array}$ & $\begin{array}{l}\text { 46; Core: } 58 \text { (54-60); } 32 \\
\text { Rim: } 58 \text { (52-63); } 28\end{array}$ & $\begin{array}{l}\text { 40; Core: } 84 \text { (81-92); } 41 \\
\text { Rim: } 84 \text { (79-88); } 32\end{array}$ & $\begin{array}{l}\text { 14; Core: } 76 \text { (74-79); } 8 \\
\text { Rim: } 77 \text { (75-78); } 7\end{array}$ & $<1$ & $\mathrm{~T}$ \\
\hline 6 & $68 \mathrm{R} 4,121-124 \mathrm{~cm}$ & 621.73 & 40 & $\begin{array}{l}\text { Olivine } \\
\text { gabbro }\end{array}$ & $\begin{array}{l}\text { Medium grained; } \\
\text { strongly altered; } \\
\text { Host of felsic Vein-S }\end{array}$ & $\begin{array}{l}\text { 50; Core: } 54 \text { (52-56); } 5 \\
\text { Rim: } 54 \text { (53-55); } 4\end{array}$ & $\begin{array}{l}\text { 40; Core: } 73 \text { (73-74); } 3 \\
\text { Rim: } 72 \text { (72-73); } 2\end{array}$ & 10; Core: 76 (75-76); 3 & $<1$ & $\mathrm{~T}$ \\
\hline 7 & $85 \mathrm{R} 3,83-90 \mathrm{~cm}$ & 754.08 & 35 & $\begin{array}{l}\text { Oxide } \\
\text { bearing } \\
\text { gabbro }\end{array}$ & $\begin{array}{l}\text { Medium grained; } \\
\text { strongly altered; } \\
\text { Host of felsic Vein-D }\end{array}$ & $\begin{array}{l}\text { 36; Core: } 41 \text { (36-45); } 15 \\
\text { Rim: } 30 \text { (22-44); } 15\end{array}$ & $\begin{array}{l}\text { 60; Core: } 71 \text { (67-76); } 12 \\
\text { Rim: } 69 \text { (65-74); } 6\end{array}$ & - & $<1$ & 4 \\
\hline
\end{tabular}

Notes: $\mathrm{mbsf}=$ meter below sea floor; Vol (\%): proportion of host gabbro in the thin section; Vein-S: Felsic vein with sharp chemical and textural boundaries with the host gabbros, Vein-R: Felsic vein with sharp chemical boundaries but textural continuity from the host gabbros; Vein-D: Felsic vein with diffused chemistry and texture of minerals in vein and in the host rock;

An $(\mathrm{mol} . \%)=100 \times \mathrm{Ca} /(\mathrm{Ca}+\mathrm{Na}+\mathrm{K}), \mathrm{Fo}(\mathrm{mol} . \%)=100 \times \mathrm{Mg} /(\mathrm{Mg}+\mathrm{Fe}) ; \mathrm{Mg} \#($ mol. $\%)=100 \times \mathrm{Mg} /\left(\mathrm{Mg}+\mathrm{Fe}^{2+}\right) ;(-)$ : no presence; T: Trace amount. More details about core samples can

be found at http:// publications.iodp.org/proceedings/360 
Table 2. Detailed characteristics of studied felsic vein samples-Hole U1473A.

\begin{tabular}{|c|c|c|c|c|c|c|c|c|c|c|c|c|c|}
\hline \multirow[b]{2}{*}{ No } & \multirow{2}{*}{$\begin{array}{l}\text { Leg 360-Hole } \\
\text { U1473A-Sample }\end{array}$} & \multirow{2}{*}{$\begin{array}{l}\text { Depth } \\
\text { (mbsf) }\end{array}$} & \multirow{2}{*}{ Vol (\%) } & \multirow{2}{*}{$\begin{array}{l}\text { Domain } \\
\text { Lithology }\end{array}$} & \multirow{2}{*}{$\begin{array}{c}\text { General } \\
\text { Comments }\end{array}$} & \multicolumn{8}{|c|}{ Felsic Rocks-Mineral Mode (\%) } \\
\hline & & & & & & $\begin{array}{l}\text { Plagioclase Modal; An } \\
\quad \text { Mean (Range); } N\end{array}$ & $\begin{array}{l}\text { Orthopyroxene Modal; } \\
\text { Mg\# Mean (Range); }\end{array}$ & $\begin{array}{c}\text { Brown } \\
\text { Amphibole }\end{array}$ & $\begin{array}{l}\text { Fe-Ti } \\
\text { Oxide }\end{array}$ & Quartz & Apatite & Zircon & Biotite \\
\hline 1 & $41 \mathrm{R} 2,26-31 \mathrm{~cm}$ & 373.11 & 80 & $\begin{array}{l}\text { Felsic vein } \\
\text { Diorite }\end{array}$ & $\begin{array}{l}\text { Planar felsic } \\
\text { Vein-S }\end{array}$ & $\begin{array}{l}\text { 60; Core: } 32 \text { (23-35); } \\
\text { 12 Rim: } 24 \text { (15-33); } 11\end{array}$ & - & 15 & 13 & - & 7 & 3 & 2 \\
\hline 2 & $64 \mathrm{R} 2,110-113 \mathrm{~cm}$ & 578.78 & 80 & $\begin{array}{l}\text { Felsic vein } \\
\text { Tonalite }\end{array}$ & $\begin{array}{c}\text { Comb-like } \\
\text { planar felsic } \\
\text { Vein-S }\end{array}$ & $\begin{array}{c}\text { 60; } \text { Core }_{1}: 38(38-39) ; 2 \\
\operatorname{Rim}_{1}: 37(36-37) ; 2 \\
\text { Core }_{2}: 6(2-11) ; 6 \\
\operatorname{Rim}_{2}: 8(8-9) ; 3\end{array}$ & 1; Core: $66 ; 1$ Rim: $66 ; 1$ & 6 & 7 & 25 & 1 & $\mathrm{~T}$ & - \\
\hline 3 & $64 \mathrm{R} 2,128-133 \mathrm{~cm}$ & 578.96 & 30 & $\begin{array}{l}\text { Felsic vein } \\
\text { Diorite }\end{array}$ & $\begin{array}{l}\text { Planar felsic } \\
\text { Vein-S }\end{array}$ & $\begin{array}{l}\text { 60; Core: } 27 \text { (15-38); } 17 \\
\text { Rim: } 21 \text { (15-28); } 12\end{array}$ & - & 25 & 8 & 3 & 1 & 3 & $<1$ \\
\hline 4 & $66 \mathrm{R} 4,46-49 \mathrm{~cm}$ & 601.82 & 45 & $\begin{array}{l}\text { Felsic vein_- } \\
\text { Tonalite }\end{array}$ & $\begin{array}{c}\text { Network } \\
\text { felsic Vein-R }\end{array}$ & $\begin{array}{l}\text { 65; Core: } 20 \text { (10-28); } 23 \\
\text { Rim: } 15 \text { (6-26); } 23\end{array}$ & - & 10 & 2 & 22 & $<1$ & 1 & $<1$ \\
\hline 5 & $66 \mathrm{R} 5,1-7 \mathrm{~cm}$ & 602.83 & 20 & $\begin{array}{l}\text { Felsic vein_- } \\
\text { Quartz diorite }\end{array}$ & $\begin{array}{l}\text { Branched } \\
\text { felsic Vein-R }\end{array}$ & $\begin{array}{l}\text { 50; Core: } 16 \text { (6-21); } 19 \\
\text { Rim: } 10 \text { (4-21); } 18\end{array}$ & - & 36 & 1 & 13 & - & $<1$ & - \\
\hline 6 & $68 \mathrm{R} 4,121-124 \mathrm{~cm}$ & 621.73 & 60 & $\begin{array}{l}\text { Felsic vein_ } \\
\text { Diorite }\end{array}$ & $\begin{array}{l}\text { Lower part of } \\
\text { large planar } \\
\text { felsic Vein-S }\end{array}$ & $\begin{array}{c}\text { 70; Core } 1: 31(25-34) ; 8 \\
\operatorname{Rim}_{1}: 21(13-33) ; 7 \\
\text { Core }_{2}: 10(5-15) ; 6 \\
\operatorname{Rim}_{2}: 13(3-17) ; 5\end{array}$ & 7; Core: 63 (62-64); 3 & 10 & 8 & - & 5 & - & $<1$ \\
\hline 7 & $85 \mathrm{R} 3,83-90 \mathrm{~cm}$ & 754.08 & 65 & $\begin{array}{l}\text { Felsic vein } \\
\text { Diorite }\end{array}$ & $\begin{array}{c}\text { Network } \\
\text { felsic Vein-D }\end{array}$ & $\begin{array}{l}\text { 67; Core: } 31 \text { (27-35); } 16 \\
\text { Rim: } 25 \text { (19-31); } 16\end{array}$ & $\begin{array}{l}\text { 5; Core: } 57 \text { (54-63); } 10 \\
\text { Rim: } 56 \text { (53-64); } 7\end{array}$ & 3 & 15 & - & 10 & $<1$ & $<1$ \\
\hline
\end{tabular}

Notes: Vol (\%): proportion of felsic vein in thin section. The others are the same as those in Table 1. 
Table 3. Summary of the studied felsic vein types and mineral characteristics-Hole U1473A.

\begin{tabular}{|c|c|c|c|}
\hline \multirow{2}{*}{ Mineral } & \multicolumn{3}{|c|}{ Felsic Vein Types } \\
\hline & Vein-S & Vein-D & Vein-R \\
\hline Plagioclase & $\begin{array}{c}\text { Fine-coarse grained, subhedral-euhedral, } \\
\text { weak-strong zonation, } \\
\text { An (mol.\%): 3-40 }\end{array}$ & $\begin{array}{l}\text { Fine-medium grained, same size with host } \\
\text { plagioclase, sub-euhedral, } \\
\text { An (mol.\%): } 20-35\end{array}$ & $\begin{array}{c}\text { Continuous twinning from plagioclase in the } \\
\text { host gabbros, } \\
\text { An (mol. } \%): 4-25\end{array}$ \\
\hline Brown amphibole & $\begin{array}{l}\text { Fine-coarse grained, subhedral-euhedral, } \\
\text { brownish-dark brown; } \\
\mathrm{TiO}_{2} \text { (wt.\%): 1-3.5 } \\
\mathrm{SiO}_{2} \text { (wt.\%): 43-52 }\end{array}$ & $\begin{array}{l}\text { Fine grained, sub-euhedral, brownish; } \\
\mathrm{TiO}_{2} \text { (wt.\%): 1-1.5 } \\
\mathrm{SiO}_{2} \text { (wt.\%): } 48-50\end{array}$ & $\begin{array}{l}\text { Continuity from the clinopyroxene in the host } \\
\text { gabbro, anhedral-subhedral; } \\
\mathrm{TiO}_{2} \text { (wt.\%): 1-2 } \\
\mathrm{SiO}_{2} \text { (wt.\%): } 47-53\end{array}$ \\
\hline Quartz & Myrmekite or interstitial fine grains aggregate & - & $\begin{array}{l}\text { Same size, shape, and modal } \% \text { as those of the } \\
\text { olivine in the host olivine gabbro }\end{array}$ \\
\hline Zircon & $\begin{array}{l}\text { Up to } 3 \text { (modal\%) total REEs (ppm): } \\
\qquad 900-2200\end{array}$ & Rare, very few grains can be observed & $\begin{array}{l}\text { Few grains are observed, total REEs (ppm): } \\
\qquad 6200-11200\end{array}$ \\
\hline Apatite & \multicolumn{2}{|c|}{$\begin{array}{c}\text { Up to }>10 \text { (modal\%) in both } 2 \text { felsic vein types; subhedral-euhedral, rounded fine grains, or anhedral } \\
\text { exsolved in plagioclase; intimately associated with Fe-Ti oxides }\end{array}$} & 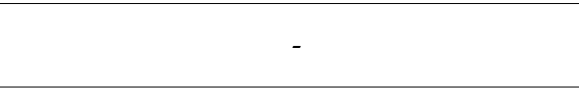 \\
\hline Fe-Ti oxides & \multicolumn{2}{|c|}{$\begin{array}{c}\text { Up to } 15 \text { (modal\%) in both } 2 \text { felsic vein types, including ilmenite and Ti-magnetite relatively pure, } \\
\text { homogeneous compositions }\end{array}$} & Lesser abundances, 1-2 (modal\%) \\
\hline
\end{tabular}

Note: REEs = Rare Earth elements. The others are the same as those in Table 1. 


\subsubsection{Host Gabbros}

The gabbros hosting felsic veins show coarse- to medium-grained, equigranular textures and contain plagioclase and clinopyroxene, ( \pm olivine) as the predominant phases. Small proportions of sulfides and Fe-Ti oxides are present as accessory minerals.

Plagioclase proportion ranges from 43 to $50 \%$ in the four olivine gabbros, and extends up to $70 \%$ in the two gabbros. The proportion is lower (36\%) in the studied oxide-bearing gabbro. Plagioclase grains are generally equigranular, coarse $(>5 \mathrm{~mm})$ to medium $(1-5 \mathrm{~mm})$ grained, subhedral to anhedral and are interlocking with clinopyroxene and olivine.

Clinopyroxene is the second most abundant phase, varying inversely with plagioclase abundance, ranging from $30-60 \%$ with subhedral to anhedral granular texture. It is often present as coarse- to medium-grained phases containing numerous small blebs (30-150 $\mu \mathrm{m})$ of brown amphibole, forming symplectitic texture.

Olivine is typically anhedral granular; modal amounts vary from $7-18 \%$ in four olivine gabbros. Orthopyroxene and brown amphibole are subordinate phases ( $<1$ vol.\%) ubiquitously in most of the thin sections (Figure 2a,c). They often occur as thin selvages between olivine and plagioclase or thin rims around olivine and clinopyroxene with irregular shapes.
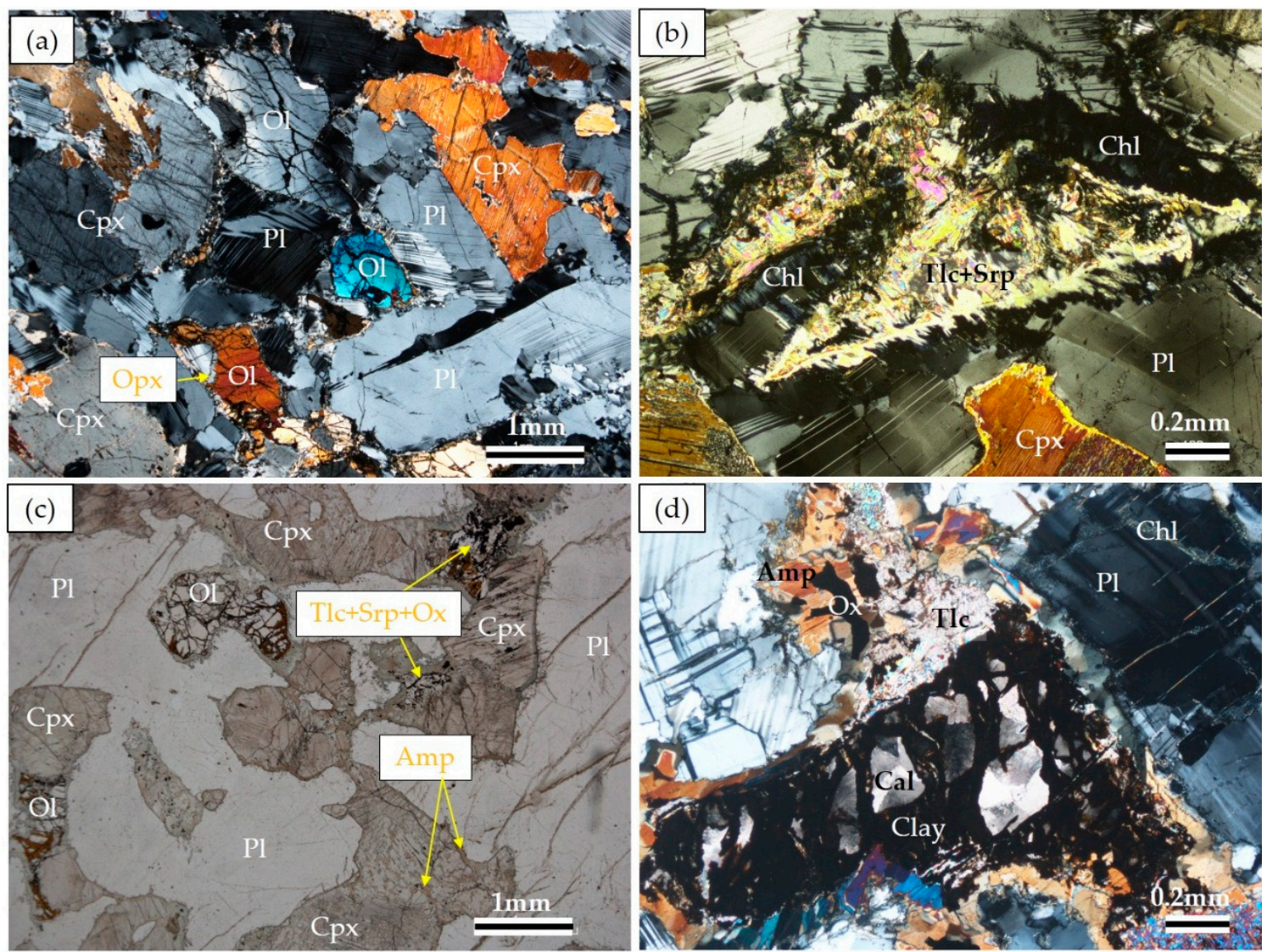

Figure 2. Photomicrographs of the host olivine gabbro IODP Hole U1473A. (a,b) Sample 66R5, 1-7 cm; orthopyroxene occurs as a thin rim between olivine and plagioclase; olivine is completely replaced by talc and serpentine, plagioclase is replaced by chlorite; (c) Sample 68R4, 121-124 cm; clinopyroxene grains include small (30-150 $\mu \mathrm{m})$ blebs of brown amphibole. (d) Sample 41R2, 26-31 cm; Calcite pseudomorphing olivine. Ol: Olivine. Pl: Plagioclase. Cpx: Clinopyroxene. Opx: Orthopyroxene. Amp: Amphibole. Tlc: Talc. Srp: Serpentine. Cal: Calcite. Chl: Chlorite. Ox: Fe-Ti oxide.

All the samples underwent moderate to strong alteration (Figure $2 b-d$ ). Some olivine grains are completely converted to serpentine, talc, and Fe-Ti oxide aggregate. Calcite and clay pseudomorphing 
olivine are also observed in some thin sections. Plagioclase and clinopyroxene show less effect of hydrothermal alteration than olivine. Clinopyroxene is partially replaced by green-colorless actinolitic amphibole while chlorite develops along the grain boundaries between altered olivine and plagioclase or filling in veins in plagioclase at a later hydrothermal stage.

\subsubsection{Felsic Veins}

Felsic veins are generally planar or branched network crosscutting the host gabbros. The vein minerals often show strong zoning pattern. Using $X$-ray mapping technique, felsic veins can be easily distinguished by higher concentrations of $\mathrm{Si}, \mathrm{Na}, \mathrm{Fe}$, and $\mathrm{Ti}$ components, but lower in $\mathrm{Ca}$ and $\mathrm{Al}$ concentrations than those of their host gabbros.

Mineral assemblages of the felsic rocks include plagioclase, amphibole, Fe-Ti oxides, \pm quartz, \pm orthopyroxene. Accessory minerals are zircon, apatite, \pm titanite, \pm biotite, \pm K-feldspar; secondary minerals are pale green-colorless amphibole, \pm carbonate, \pm clay materials. On the International Union of Geological Sciences (IUGS) classification scheme of plutonic rocks [27], the felsic rocks are classified as hornblende gabbros or hornblende bearing anorthosites and quartz-bearing anorthosites (Figure 3a) sensu stricto. In the quartz-alkali felspar-plagioclase (QAP) diagram, felsic rocks range from diorites, quartz diorites to tonalites (Figure 3b).

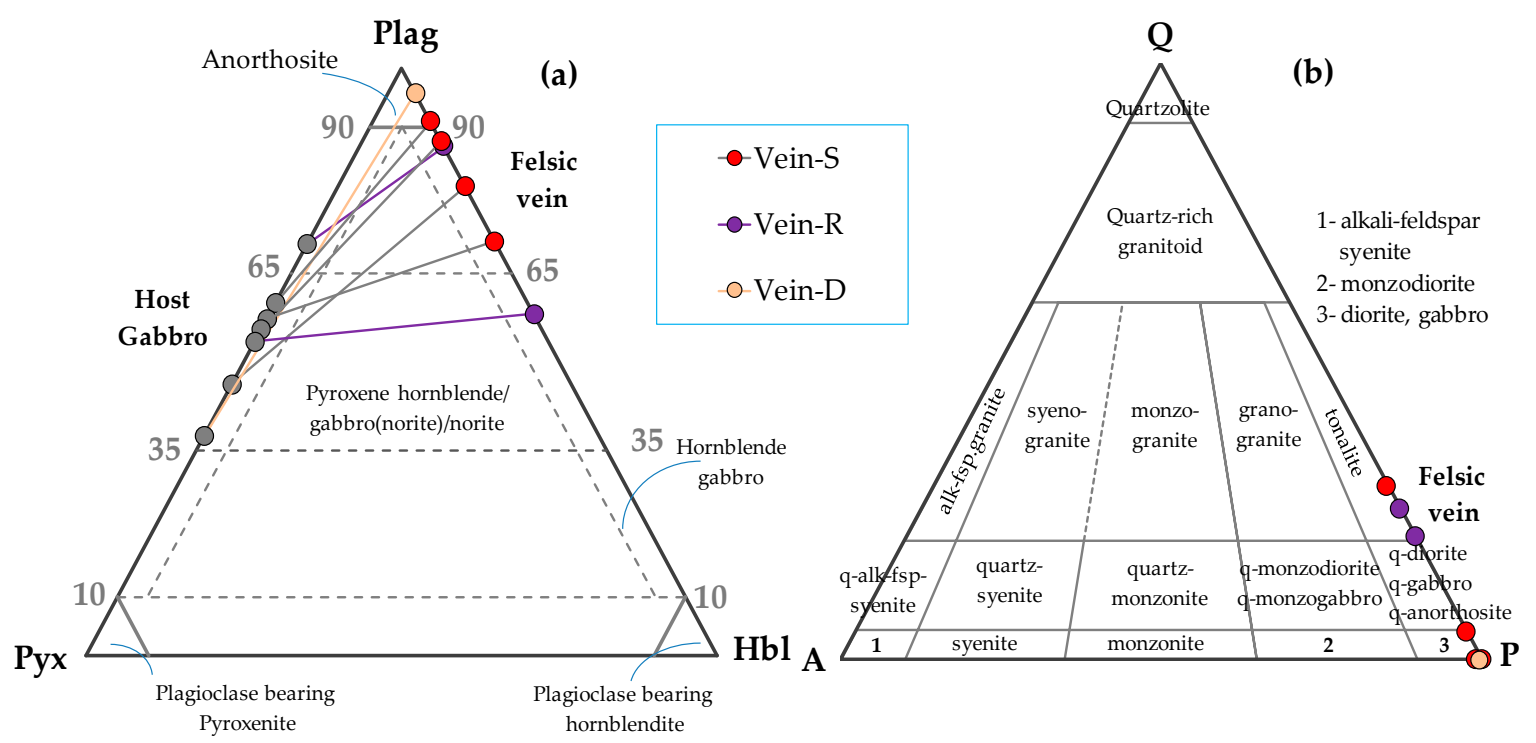

Figure 3. International Union of Geological Sciences (IUGS) classification of felsic rocks-Hole U1473A. (a) Plagioclase-pyroxene-hornblende classification scheme; (b) QAP diagram. Symbols with the connected lines indicate pairs of host gabbros (gray)-felsic rocks (colorful) in the same samples.

Based on petrological and geochemical characteristics of vein minerals, nature of vein boundaries, and their relationship with the host gabbros, we divide felsic rocks into three types: (1) the Vein-S/felsic rock with sharp boundaries is characterized by the sharp chemical and textural boundaries, (2) the Vein-R/felsic rock with features of replacement processes is typified by the sharp chemical boundaries but in textural continuity with the host gabbros, and the (3) Vein-D/felsic rock with diffused boundaries contains the diffused chemistry and texture of minerals both in vein and in the host rock.

\section{a. Diverse Occurrences of Felsic Veins in the Hole U1473A}

\section{a.1. Vein-S/ Felsic Rock with Sharp Boundaries}

Felsic rocks with sharp boundaries are characterized by differences in both texture and chemical composition from their host gabbros. The host rock is typified by anhedral, fine- to medium-grained plagioclase, clinopyroxene, and olivine while the felsic part is dominated by relatively 
subhedral-euhedral coarser grains of plagioclase and amphibole. The compositions of the cores and the rims of the minerals in the host rock are less variable while the vein minerals often show strong normal zoning patterns. Sharp chemical changes from the host to the felsic vein are observed and highlighted in Figure 4b,c.
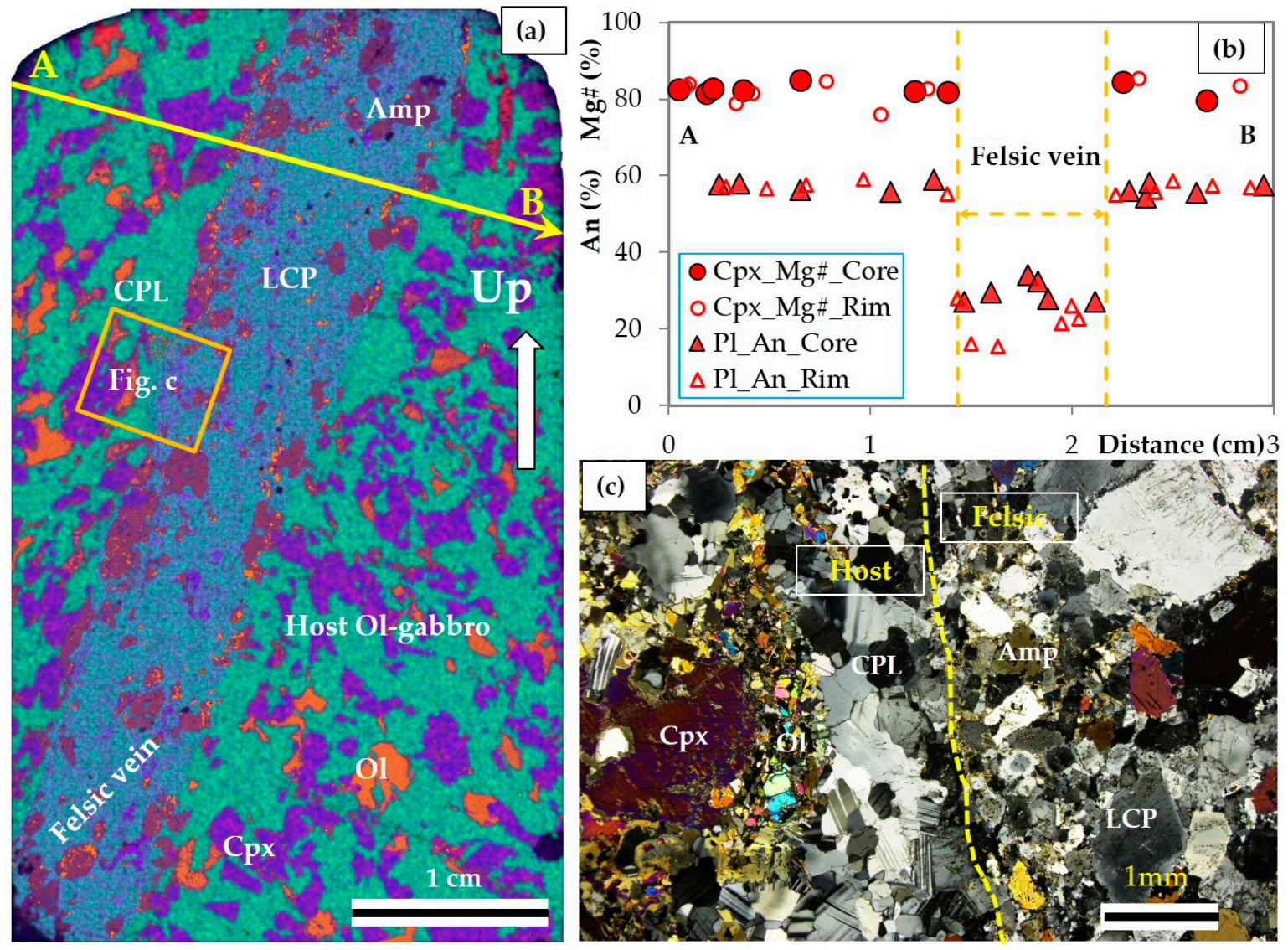

Figure 4. Felsic rock and host olivine gabbro interaction. (a) Phases X-ray mapping image of sample 64R2, 128-133 cm. Notice the sharp planar shape of the vein. (b) Chemical profile across the felsic vein. (c) Photomicrograph of the felsic boundary. Pl: Plagioclase. CPL: Calcic plagioclase. LCP: Less calcic plagioclase. Cpx: Clinopyroxene. Ol: Olivine.

\section{a.2. Vein-R/Felsic Rocks with Features of Replacement Processes}

The felsic rocks with features of replacement processes are characterized by textural continuity between felsic and host minerals although they are distinctive in mineral chemistry. As shown in Figure 5, host rock is an olivine gabbro containing calcic plagioclase $\left(\mathrm{An}_{58}\right)$, clinopyroxene and less olivine whereas vein minerals are mainly less calcic plagioclase $\left(\mathrm{An}_{13}\right)$, amphibole and quartz. Proportions of the felsic plagioclase and amphibole are comparable to those of the host plagioclase and clinopyroxene.

In some coarse-grained plagioclase in the host, albite twins are continuous from the host to the felsic part, extending to the other side of the host while their anorthite contents show a sharp geochemical interface (Figures $5 b-d$ and 6 ). It is interesting to note that the plagioclase with albite twins parallel to the boundary between the host and the vein is also observed. This continuous texture of albite twins from the host to the felsic vein could not be formed by epitaxial growth from the host plagioclase. The boundary between host calcic plagioclase and the less calcic (felsic) plagioclase is often zigzag, likely related to the direction of the twin plane (Figure 6c). Micro veinlets/networks of less calcic plagioclase are also observed (Figure 6b). 

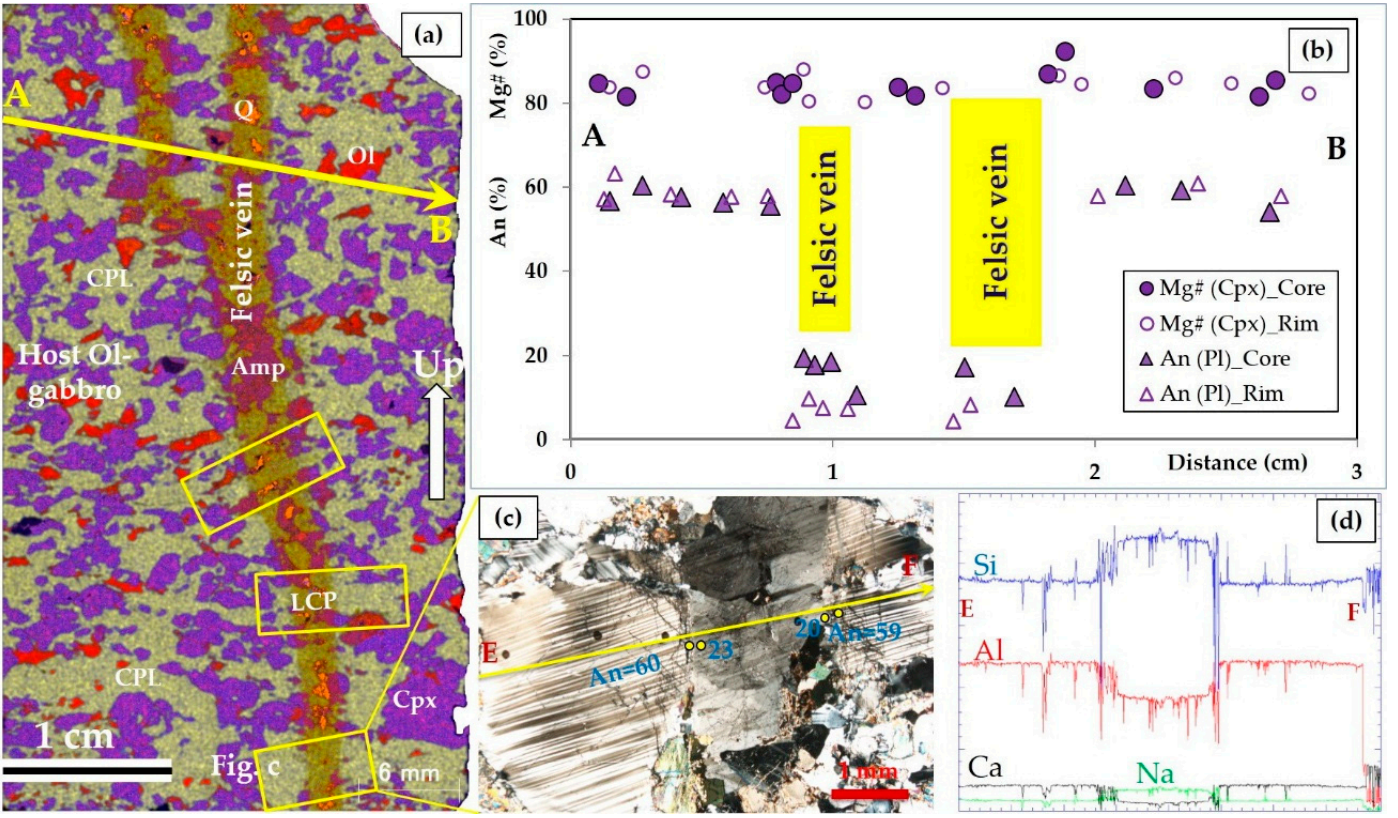

Figure 5. Host olivine gabbro-felsic rock interaction, sample 66R5, 1-7 cm. (a) Phases X-ray mapping image of the whole thin section; notice the continuous texture between the felsic vein and the host olivine gabbro; (b) geochemical profile across felsic vein. (c) Coarse grain of calcic plagioclase (CPL) was partly replaced by less calcic plagioclase (LCP). (d) Semi-quantitative chemical profile of plagioclase shown in (c).
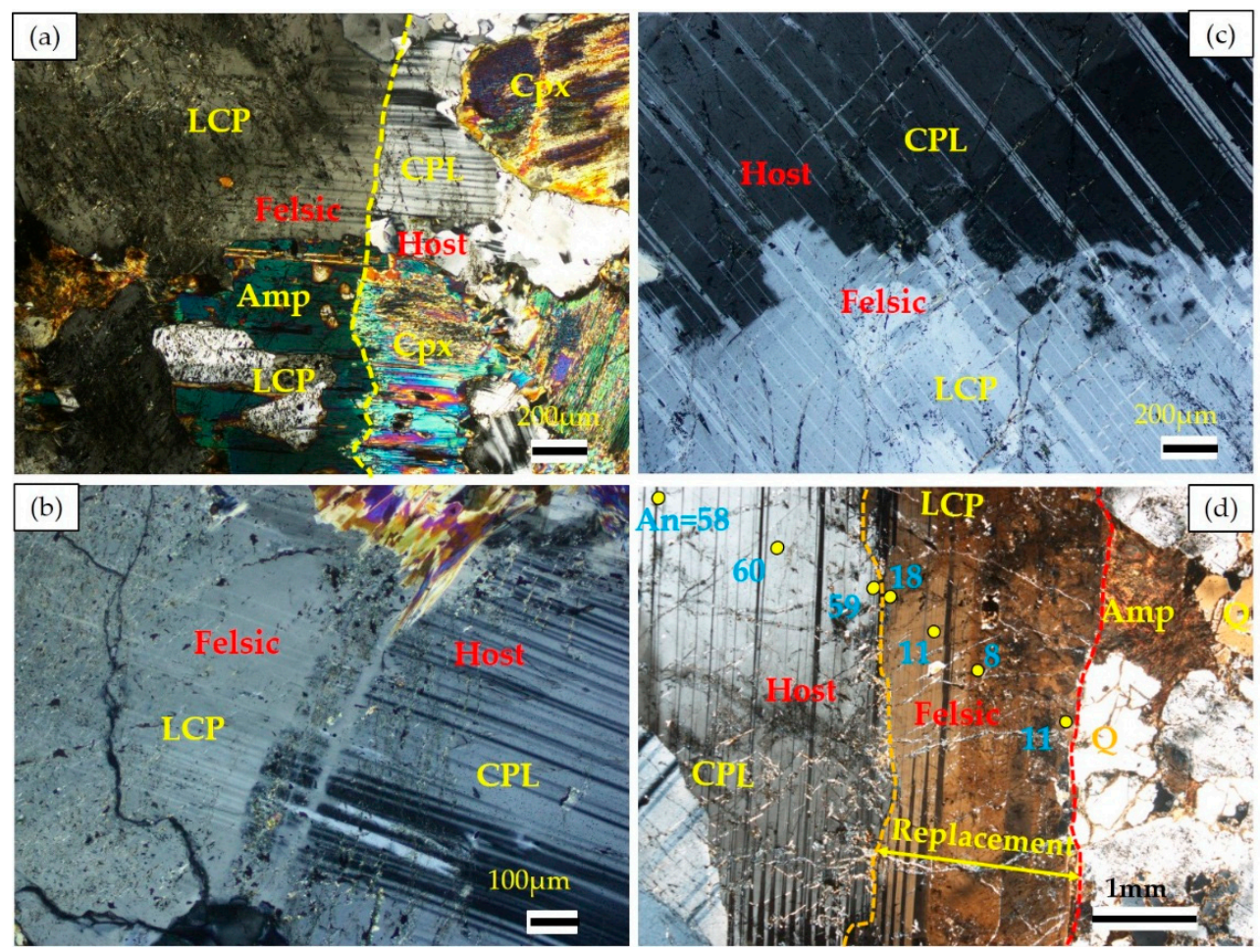

Figure 6. Closed-up replacement texture photomicrographs at felsic veins boundaries-Hole U1473A. (a,b) Sample 66R5, 1-7 cm; clinopyroxene and calcic plagioclase were partially converted to brown amphibole and less calcic plagioclase, respectively. (c,d) Sample 66R4, 46-49 cm; reaction interface and the replacement of plagioclase. CPL: Calcic plagioclase. LCP: Less calcic plagioclase. Cpx: Clinopyroxene. Amp: Amphibole. Q: Quartz. 
Felsic brown amphiboles usually occur in contact with the host clinopyroxenes. The texture of less calcic plagioclase included in brown amphibole is similar to sub-ophitic texture in the host gabbros (Figure 6a). The continuous twinning of plagioclase and the preservation of the host texture, such as clinopyroxene-brown amphibole relationships strongly support a pseudomorphic replacement from the host rock. These pseudomorphs are a typical feature of dissolution- reprecipitation mechanisms observed in metamorphic rocks [28-33].

We did not find any traces of relic olivine or orthopyroxene in this vein type, instead, we observed the appearance of quartz, red Fe-bearing and $\mathrm{Mg}$-rich $(\mathrm{MgO}=20-25 \%)$ micro-grained phases. It is noteworthy that the aggregation of quartz and $\mathrm{Mg}$-bearing phases presents in the felsic vein with a comparable proportion, size, and shape to that of the host olivine (Tables 1-3; Figure 7).
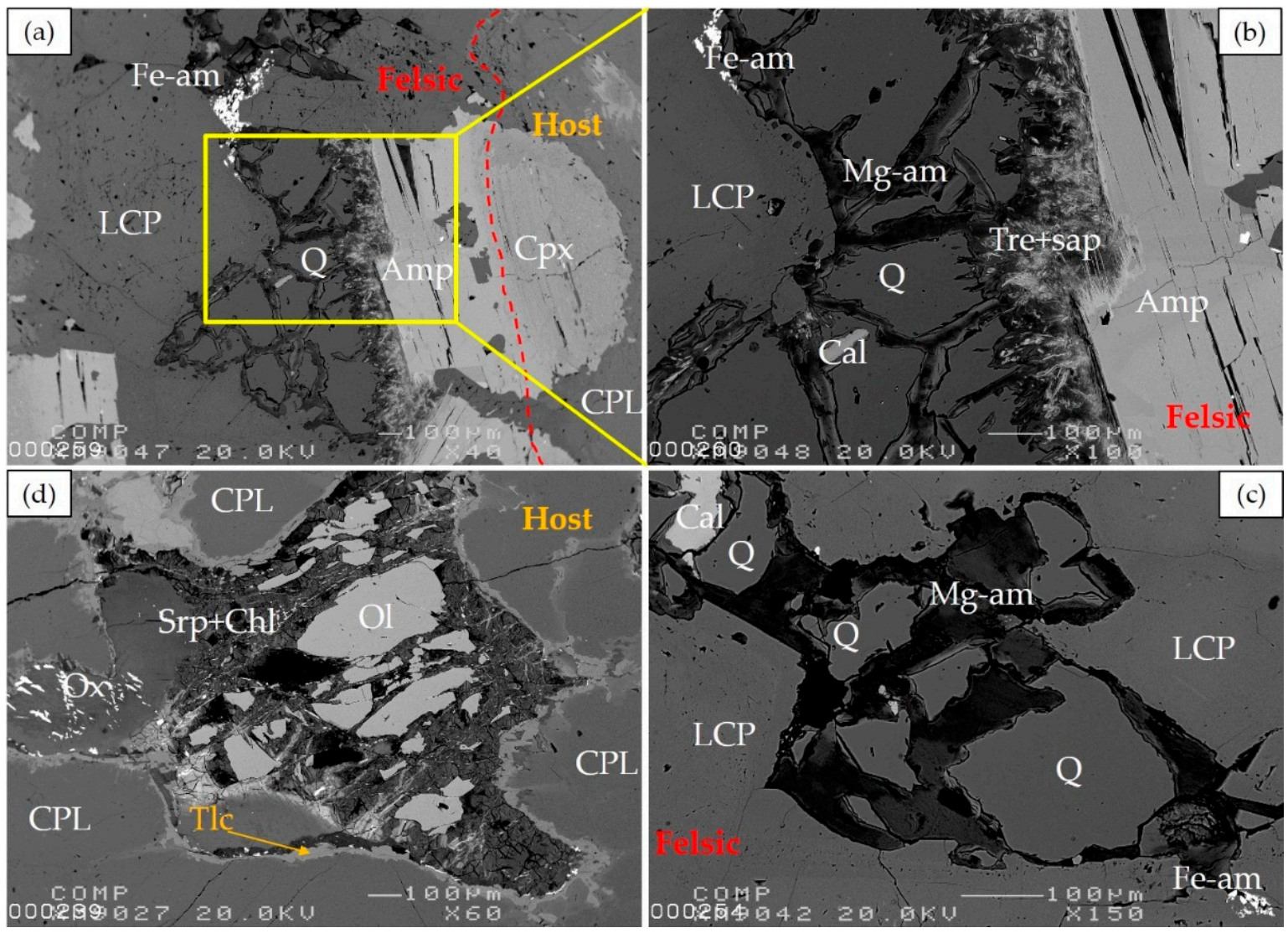

Figure 7. Occurrence of felsic-quartz and a comparison with host-olivine alteration, sample 66R5, 1-7 $\mathrm{cm}$. (a-c) Quartz in felsic vein. (d) Host olivine alteration texture. CPL: Calcic plagioclase. LCP: Less calcic plagioclase. Cpx: Clinopyroxene. Q: Quartz. Cal: Calcite. Fe-am: Red Fe-bearing phase. Mg-am: Mg-rich phase. Tre: Tremolite. Sap: Saponite. Amp: Brown amphibole. Ol: Olivine. Srp: Serpentine. Chl: Chlorite. Tlc: Talc. Ox: Fe-oxide.

\section{a.3. Vein-D/Felsic Rocks with Diffused Boundaries}

Felsic rocks with diffused boundaries are characterized by the textural ambiguity between felsic and host parts in thin section scale. Chemical intensity images clearly prove that the sample has two domains including different mineral assemblages (Sample 85R3, 83-90 cm). The host rock is an oxide bearing gabbro intruded by a network felsic vein with irregular-curved boundaries. The felsic part is characterized by slightly less calcic plagioclase-dominant zone coupled with the abundance of apatite and Fe-Ti oxides (Figure 8). Two different plagioclase generations corresponding to the host oxide bearing gabbro and felsic rock are observed; however, the chemical gap of the plagioclase composition in the two parts is relatively narrow, around 10 mol.\% (average of $\mathrm{An}_{41}$ and $\mathrm{An}_{31}$ for the 
host and the vein, respectively). In addition, the host plagioclase also shows a strong zoning pattern and the rim compositions are equivalent to the felsic plagioclase cores composition, making confusion in distinguishing felsic part under the microscope.

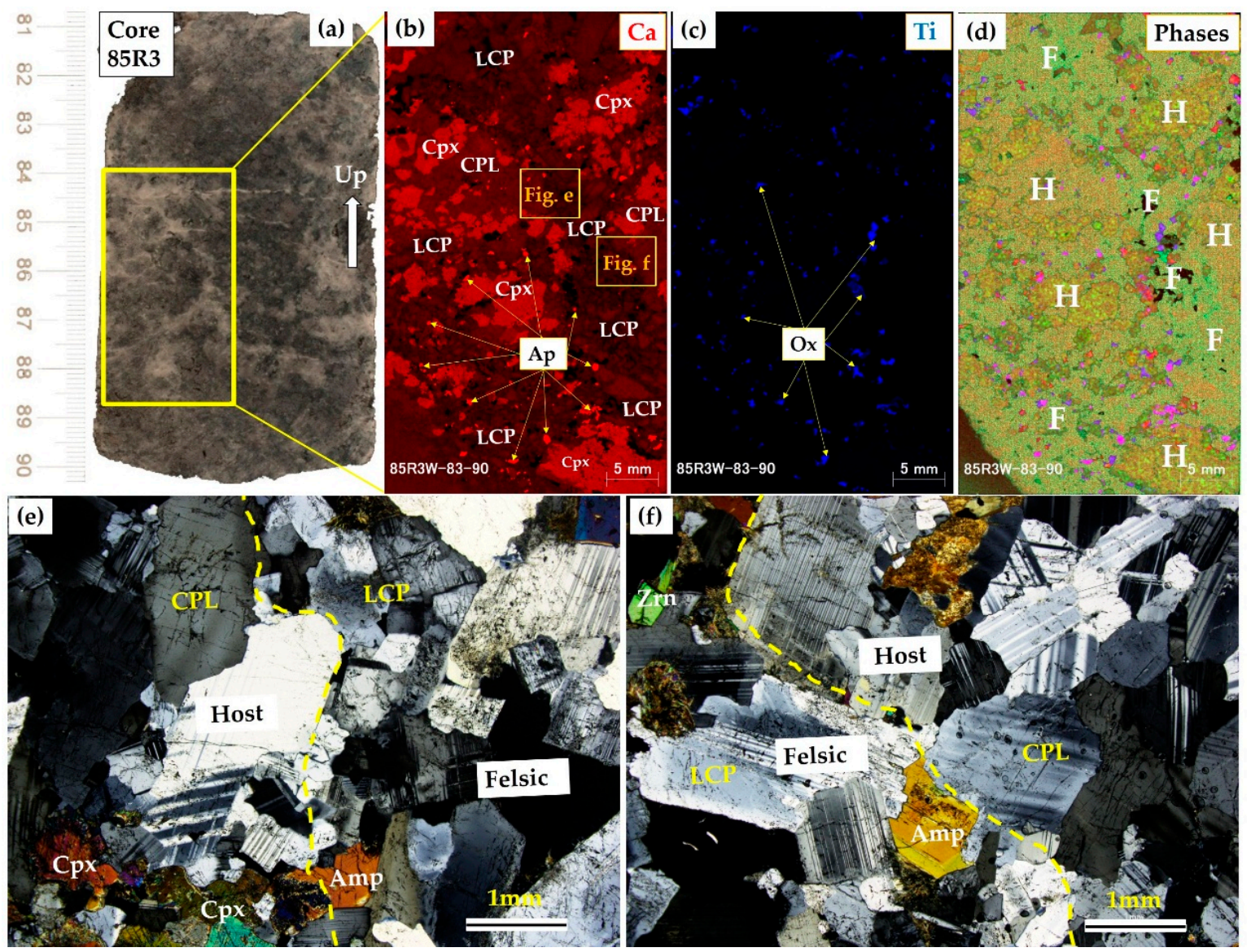

Figure 8. Felsic rock and host oxide bearing gabbro interaction, sample 85R3, 83-90 cm. (a) Core scanned photo. (b-d) Elemental and phases X-ray mapping images. (e,f) Microphotographs of the felsic boundaries. CPL: Calcic plagioclase. LCP: Less calcic plagioclase. Cpx: Clinopyroxene. Ap: Apatite. Ox: Fe-Ti oxide. Zrn: Zircon. H: Host oxide bearing gabbro. F: Felsic part.

Since the occurrence and composition of minerals in three vein types are diverse, including overlaps, we first provide the summary of mineralogical features in the three vein types (Table 3), then describe general characteristics of each mineral in all of the veins in the next section.

\section{b. General Description of Vein Mineralogy}

Plagioclase is the most abundant phase in felsic veins (50-70 vol.\%) with various grain size; most are subhedral to euhedral with strong normal zoning. There are two occurrences of plagioclase in the felsic veins: one as coarse- to fine-grained, strongly zoned crystals (Figure 9a) and another as myrmekitic intergrowths with quartz (quartz blebs up to $2 \mathrm{~mm}$ long) (Figure 9d). K-feldspar of very small size $(30-120 \mu \mathrm{m})$ also occurs in most of the veins as accessory minerals occurring interstitially between plagioclase and oxide minerals. 

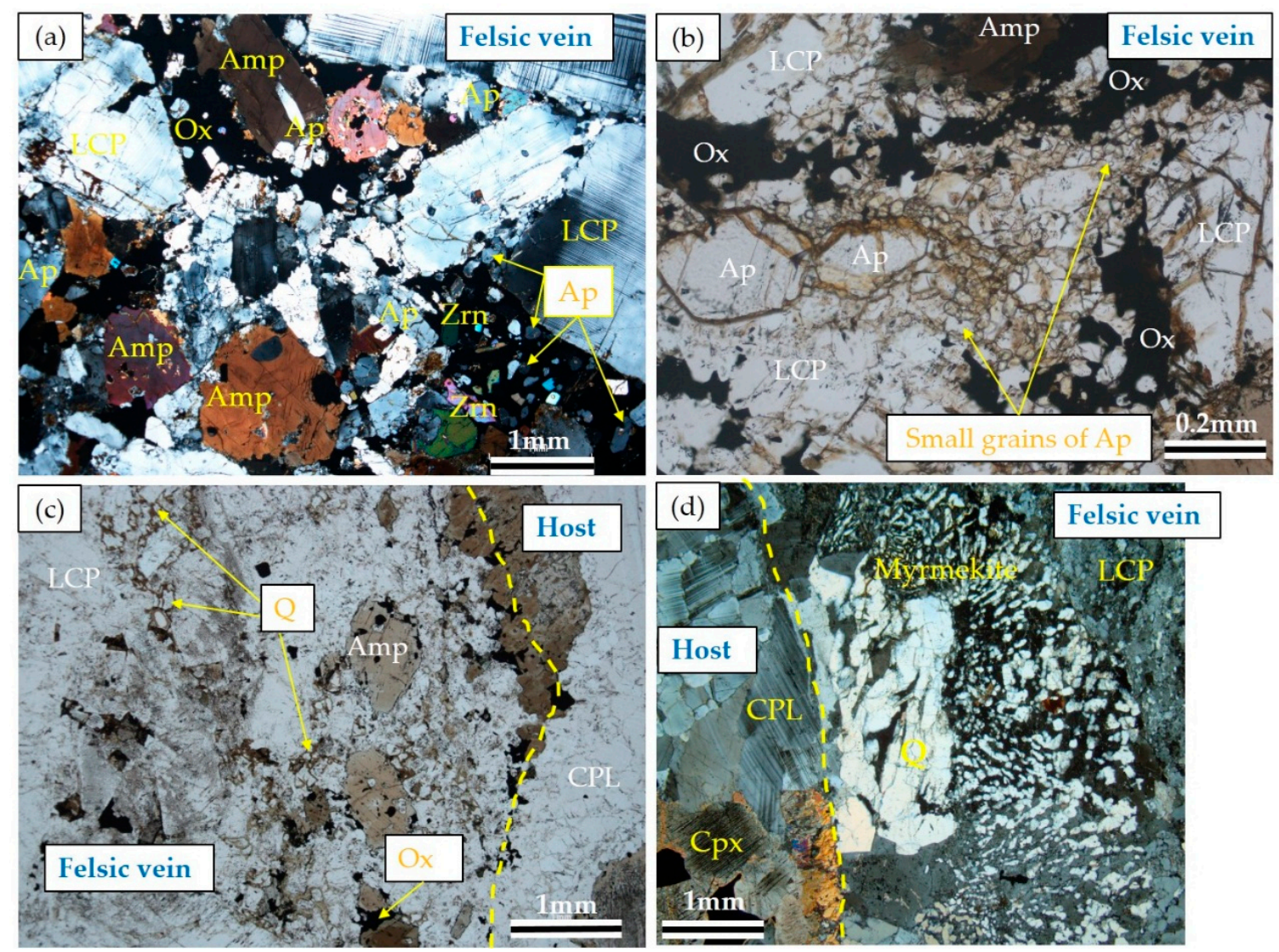

Figure 9. Photomicrographs of felsic vein Hole U1473A. (a) Sample 41R2, 26-31 cm; notice the abundance of Fe-Ti oxide, zircon, and apatite. (b) Sample 41R2, 26-31 cm; small grains of apatite in fine-grained part in felsic vein. (c) Sample 64R2, 128-133 cm; interstitial quartz in the center of the felsic vein. (d) Sample 41R3, 73-76 cm; the myrmekitic texture of quartz and plagioclase. Amp: Amphibole. CPL: Calcic plagioclase. LCP: Less calcic plagioclase. Ox: Fe-Ti oxide. Q: Quartz. Ap: Apatite. Zrn: Zircon.

Amphibole is the second most dominant phase in felsic veins. Discrete subhedral to euhedral grains are commonly observed in Vein-S and Vein-D. Whereas, brown amphibole in the Vein-R can be distinguished by the textural continuity with clinopyroxene from the host rocks. Based on their occurrences and colors, we divide the amphibole into three types: discrete grains of brown amphibole (type 1) within veins (Figure 9a-c); brown amphibole at the vein boundary (type 2) replacing and/or growing at the expense of clinopyroxene of the host gabbro (Figure 6a), and greenish-colorless amphibole (type 3).

Quartz is present in some felsic veins with significant amounts (3 up to 25 modal\%) and occurs in two modes: one as intergrowth with albite/plagioclase forming myrmekitic texture as described above; another as small, irregular interstitial grains, ranging from 0.1 to $0.5 \mathrm{~mm}$ occurring interstitially at the vein center with relatively coarser grain $(2 \mathrm{~mm}$ ) (Figure 9c,d). It is common to find quartz grains that are in optical continuity forming larger grain (up to $3 \mathrm{~mm}$ ).

Fe-Ti oxides (including mainly ilmenite and Ti-magnetite) are present in all felsic veins (up to 15 vol. \%), in high concentrations along vein boundaries or interstitial phases between large plagioclase grains. The apatite is present in most of the veins with significant amount (Table 2) in two modes: one as discrete euhedral-subhedral crystals and another as rounded micro-grains occurring in aggregate along the boundary of coarser plagioclase grains (Figure 9a,b). The occurrences of apatite are intimately related to the Fe-Ti oxides. Zircons are generally euhedral crystals, $\sim 0.1-0.6 \mathrm{~mm}$ across, present in most of the veins as an accessory phase, locally concentrated in some veins (up to 3-4 vol.\%); typically associated with Fe-Ti oxides and apatite. The biotite is yellowish brown and dark-brown with strong 
pleochroism; it is typically present as single interstitial phase between plagioclase grains or at rims of the brown amphibole.

Orthopyroxene exhibits in some felsic veins in form of anhedral-subhedral fine- to mediumgrains. They concentrate mainly along the vein boundaries, making up to $7 \mathrm{vol} \%$ of the felsic vein (Table 2).

\subsection{Analytical Methods}

The elemental distribution image of the entire thin section for all samples was mapped by a micro X-ray fluorescence machine (M4-Tornado, Bruker) at GSJ-Lab, Geological Survey of Japan, National Institute of Advanced Industrial Science and Technology. The measurements were performed under the conditions of $50 \mathrm{kV}, 600 \mu \mathrm{A}$ using a $25 \mu \mathrm{m}$ beam spot size, $20 \mu \mathrm{m} \times 20 \mu \mathrm{m}$ in 1-pixel size and 1 millisecond per pixel measure time. Finally, by using ImageJ software in Reference [34], separate elemental images were combined to make phases image for all specimens to check the distribution of minerals.

Major and minor element chemical compositions of minerals were obtained by an electron probe microanalyzer (EPMA) with a JEOL JXA-8800 system at Kanazawa University, using ZAF ( $Z$ = atomic number, $\mathrm{A}=$ absorption, $\mathrm{F}=$ characteristic fluorescence) correction software (JEOL JXA-8800, Jeol Ltd., Akishima, Tokyo, Japan). The analyses were conducted using an accelerating voltage of $20 \mathrm{kV}$ with a beam current of $20 \mathrm{nA}$ and a 3- $\mu \mathrm{m}$ diameter; X-ray peaks of elements are analyzed for $20 \mathrm{~s}$ except for $\mathrm{Ni}(30 \mathrm{~s})$. Natural and synthetic mineral standards were used to calibrate all elements. Ferric iron content in pyroxenes was estimated following the method proposed by Droop in Reference [35]. Major and minor element compositions of minerals are presented in Supplementary Tables S1-S6, and are summarized in Tables 1 and 2, Supplementary Table S8.

Trace element compositions including rare earth elements (REEs) of zircons were analyzed by LA-ICP-MS (MicroLas GeoLas Q-plus $193 \mathrm{~nm}$ ArF excimer laser system and Agilent 7500s) at Kanazawa University [36]. Each analysis was performed by single spot ablation $40 \mu \mathrm{m}$ in diameter at a $5 \mathrm{~Hz}$ repetition rate with an energy density of $8 \mathrm{~J} / \mathrm{cm}^{2}$ per pulse. Signal integration times were $50 \mathrm{~s}$ for a background interval and $50 \mathrm{~s}$ for a laser ablation interval corresponding to 250 pulse shots. Unknown samples including 2-5 target positions were analyzed between the external Standard Reference Material (SRM) of National Institute of Standard and Technology (NIST)-NIST SRM 610 through the analytical sequence. The reference NIST SRM 612 was also measured with samples for quality control of each measurement session. Trace element concentrations of other minerals were analyzed at $6 \mathrm{~Hz}$ and $8 \mathrm{~J} / \mathrm{cm}^{2}$ by ablating $60-\mu \mathrm{m}$ spot diameters for both clinopyroxene and amphibole, and $100-\mu \mathrm{m}$ spots for plagioclase. The primary calibration standard (NIST SRM 612) was analyzed at the beginning and at the end of each batch consisting of $n \leq 7$ unknown samples (including NIST SRM 614 for controlling the quality of analyses), with a linear drift correction applied between each calibration. Signal integration times were $50 \mathrm{~s}$ for a background interval and $50 \mathrm{~s}$ for a laser ablation interval corresponding to 300 pulse shots. Data reduction was facilitated using ${ }^{29} \mathrm{Si}$ as an internal standard element for all minerals. Trace and REE element compositions are listed in Supplementary Tables S6-S7.

\section{Mineral Major and Trace Composition}

\subsection{Olivine}

The forsterite content $(\mathrm{Fo}=100 \times \mathrm{Mg} /(\mathrm{Mg}+\mathrm{Fe})$ in molar proportion $)$ of olivine in the olivine gabbros ranges from $\mathrm{FO}_{72}$ to $\mathrm{FO}_{78}$. Individual olivine grains display homogeneous compositions and in each studied sample the composition does not vary much (Table 1 ). The $\mathrm{NiO}$ content is lower than the detection limit of electron probe microanalyzer (EPMA) under a conventional condition $(<0.1 \mathrm{wt} . \%)$. 


\subsection{Clinopyroxene}

Although the chemical compositions of examined samples are scattered, the average $\mathrm{Mg \#}$ $\left(\mathrm{Mg} \#=100 \times \mathrm{Mg} /\left(\mathrm{Mg}+\mathrm{Fe}^{2+}\right)\right.$ of clinopyroxene cores in olivine gabbros and gabbros ranges from 86 to 80 (except for an average of 73 in one olivine gabbro-sample 68R4, 121-124 cm), locally decreasing to 70 in one oxide-bearing gabbro. The differences between the core and rim compositions are in general $1-3$, rarely up to 6 .

Minor element ( $\mathrm{Ti}, \mathrm{Al}, \mathrm{Na}$, and $\mathrm{Mn}$ ) concentrations of clinopyroxene in the studied samples roughly show differentiation trends correlating with decreasing Mg\# (Figure 10) from olivine gabbros to oxide-bearing gabbro. As the $\mathrm{Mg} \#$ of clinopyroxenes decreases, the $\mathrm{TiO}_{2}$ and $\mathrm{Al}_{2} \mathrm{O}_{3}$ contents decrease as well. Whereas, the $\mathrm{Na}_{2} \mathrm{O}$ and $\mathrm{MnO}$ contents exhibit a slight increase and steady increase, respectively.
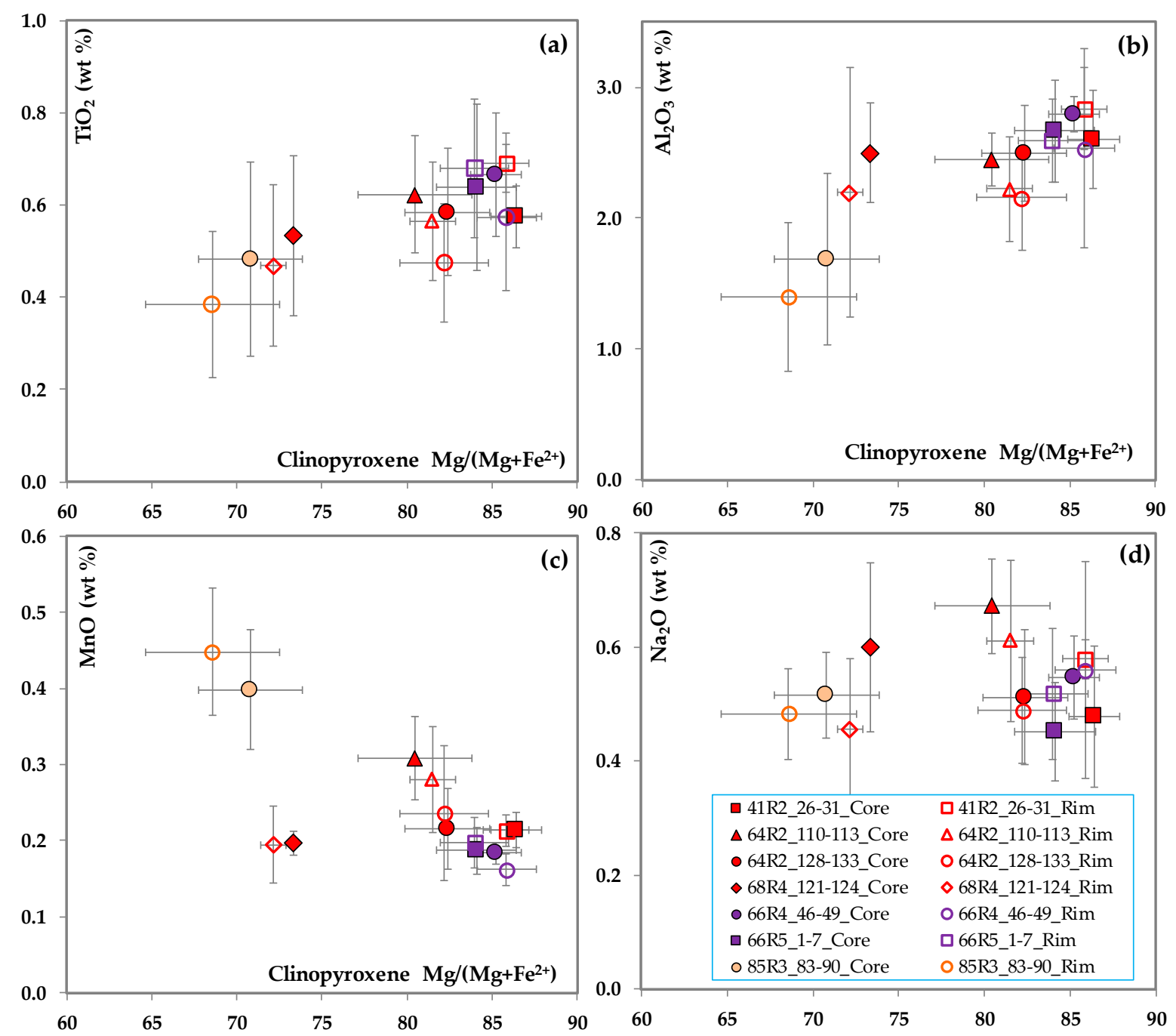

Figure 10. Clinopyroxene $\mathrm{Mg} \#$ versus minor element oxides. (a) $\mathrm{Mg} \#$ versus $\mathrm{TiO}_{2}$. (b) $\mathrm{Mg \#}$ versus $\mathrm{Al}_{2} \mathrm{O}_{3}$. (c) $\mathrm{Mg} \#$ versus $\mathrm{Na}_{2} \mathrm{O}$. (d) $\mathrm{Mg} \#$ versus $\mathrm{MnO}$. Each symbol is the average composition of 1 thin section; solid-open symbols indicate the average composition of the cores and rims, respectively. Bars are $1 \sigma$ standard deviations. 
We analyzed trace-REE compositions of clinopyroxene in three representative samples of the host gabbros, including olivine gabbros $(n=2$, hosts of Vein-S and Vein-R) and oxide bearing gabbro $(n=1$, host of Vein-D). Traces and REE concentrations of clinopyroxenes show a similar pattern with wide range of variation, from $\leq 10$ to around 300 times enriched relative to the chondrite values. Clinopyroxenes in studied samples are depleted in light REEs relative to middle and heavy REEs, with $(\mathrm{La} / \mathrm{Sm})_{\mathrm{N}}=0.1-0.67$ and $(\mathrm{La} / \mathrm{Yb})_{\mathrm{N}}=0.1-0.75$. As shown in Figure 11, in the trace element patterns of clinopyroxenes, Eu, Sr, and high field strength elements (HFSE: Zr, Hf, Ti, V) display various levels of negative anomalies compared to neighboring REEs. The clinopyroxenes in two host olivine gabbros have lower trace and REE abundances than those in the host oxide bearing gabbro. Whereas, in sample 85R3, 83-90 cm, the REE composition of clinopyroxene is strongly affected by the felsic melt, in which coarser grain has more primitive composition. The REE abundances are directly proportional to the distance to vein boundaries, and reach a maximum as high as the concentration in felsic brown amphibole at the contact with felsic Vein-D.
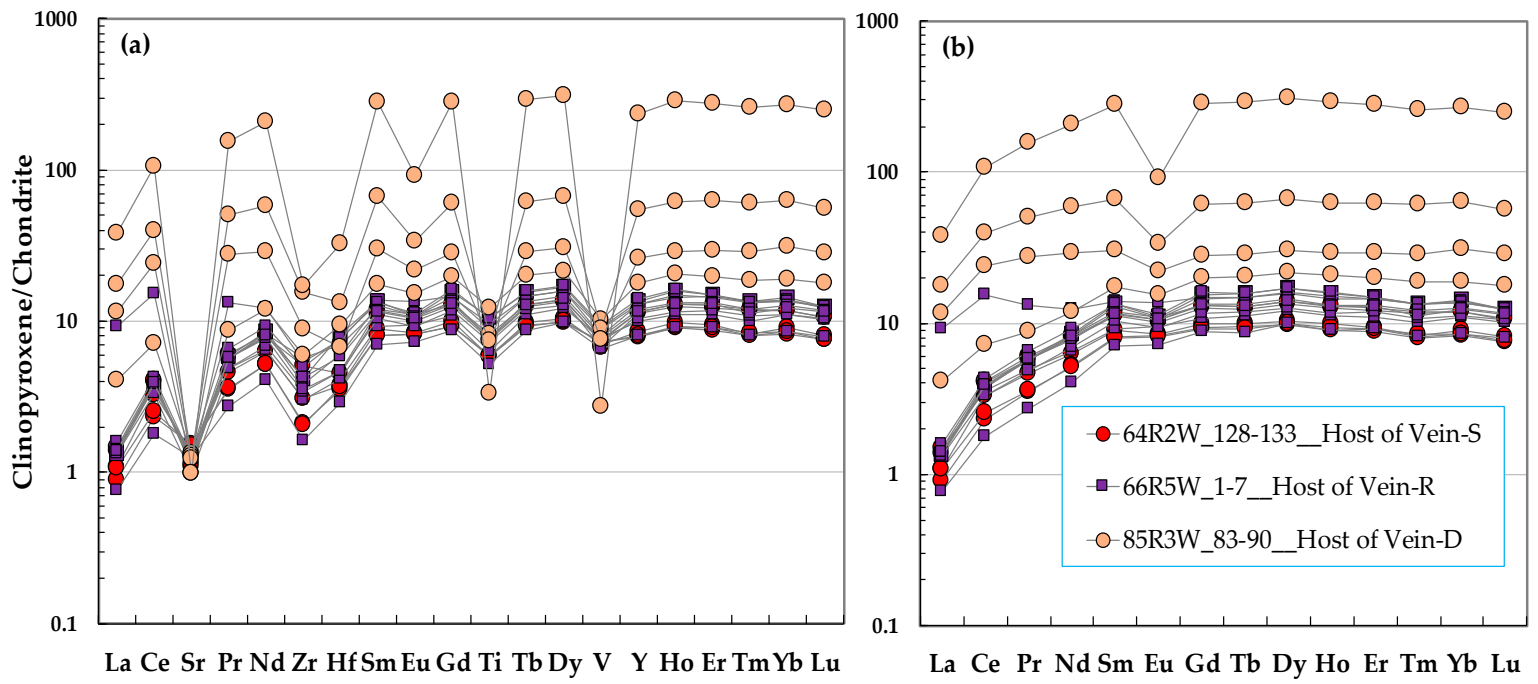

Figure 11. Chondrite-normalized trace (a) and rare earth element (REE) (b) abundances of clinopyroxenes in the host gabbros-Hole U1473A. Normalizing values are from Reference [37].

\subsection{Plagioclase}

The core composition of the plagioclase in the host gabbro samples ranges from $\mathrm{An}_{52}-\mathrm{An}_{60}$ $\left(\mathrm{An}=100 \times \mathrm{Ca} /(\mathrm{Ca}+\mathrm{Na}+\mathrm{K})\right.$ in six olivine gabbros and gabbros, extending down to $\mathrm{An}_{36}-\mathrm{An}_{45}$ in one oxide bearing gabbro.

In felsic veins, the composition of plagioclases has a wide range of variation $\left(\mathrm{An}_{2}-\mathrm{An}_{39}\right)$ and shows a normal zoning pattern. Most grains have cores of oligoclase-andesine and rims of respective albite-oligoclase. We did not find any systematic variation of total iron content from core to rim. Average compositions of studied samples are shown in Figure 12. Two different populations of plagioclase in the felsic portions are observed in samples 64R2, 110-113 cm and 68R4, 121-124 cm. In both cases, fine grains of subhedral-euhedral domains contain low-An plagioclase $\left(\mathrm{An}_{5}-\mathrm{An}_{10}\right)$ aggregate in center of veins and/or along boundaries of coarser grains with higher anorthite content $\left(\mathrm{An}_{30}-\mathrm{An}_{39}\right)$.

Figure 13 depicts trace and REE patterns of plagioclase in the felsic veins (Vein-S and Vein-R) in comparison with those in the host olivine gabbros. The most striking feature is the higher REE abundances of plagioclase in veins, up to more than one order of magnitude compared to those of plagioclase in the host gabbros. Plagioclase in veins can also be distinguished from that in the host gabbros by opposite Ti anomalies and various levels of $\mathrm{Sr}$ abundances relative to neighboring REEs. In both lithologies, plagioclases are characterized by strong positive Eu and Ba anomalies. The extent of the Eu anomaly $(\mathrm{Eu} / \mathrm{Sm}) \mathrm{N}$ is $12-21$, and locally goes down to 6-8 in rims of the host plagioclases at 
the vein boundaries. Interaction between evolved melt and the host rock is limited at the boundaries as evident from the REE enrichments at the rim of host mineral in contact with the vein.

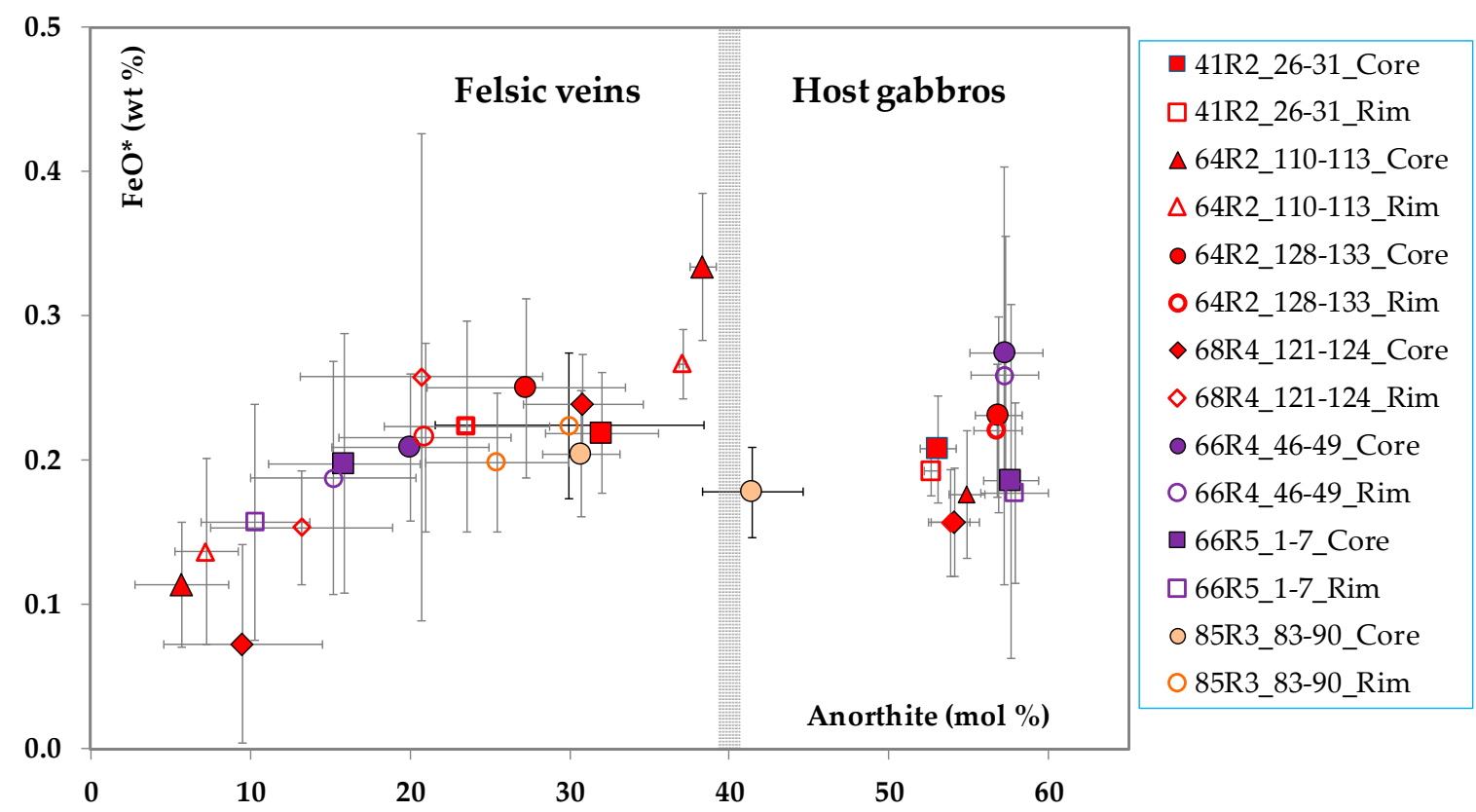

Figure 12. Average plagioclase anorthite content plotted versus $\mathrm{FeO}^{*}$ (total iron oxides, wt.\%); each point is the average of 1 domain in 1 sample and bars are $1 \sigma$ standard deviations. Same symbols and colors indicate pairs of host-felsic rocks in 1 thin section; solid and open symbols are the average composition of the cores and rims, respectively. Grey band roughly shows the geochemical boundary of host gabbros-felsic rocks.
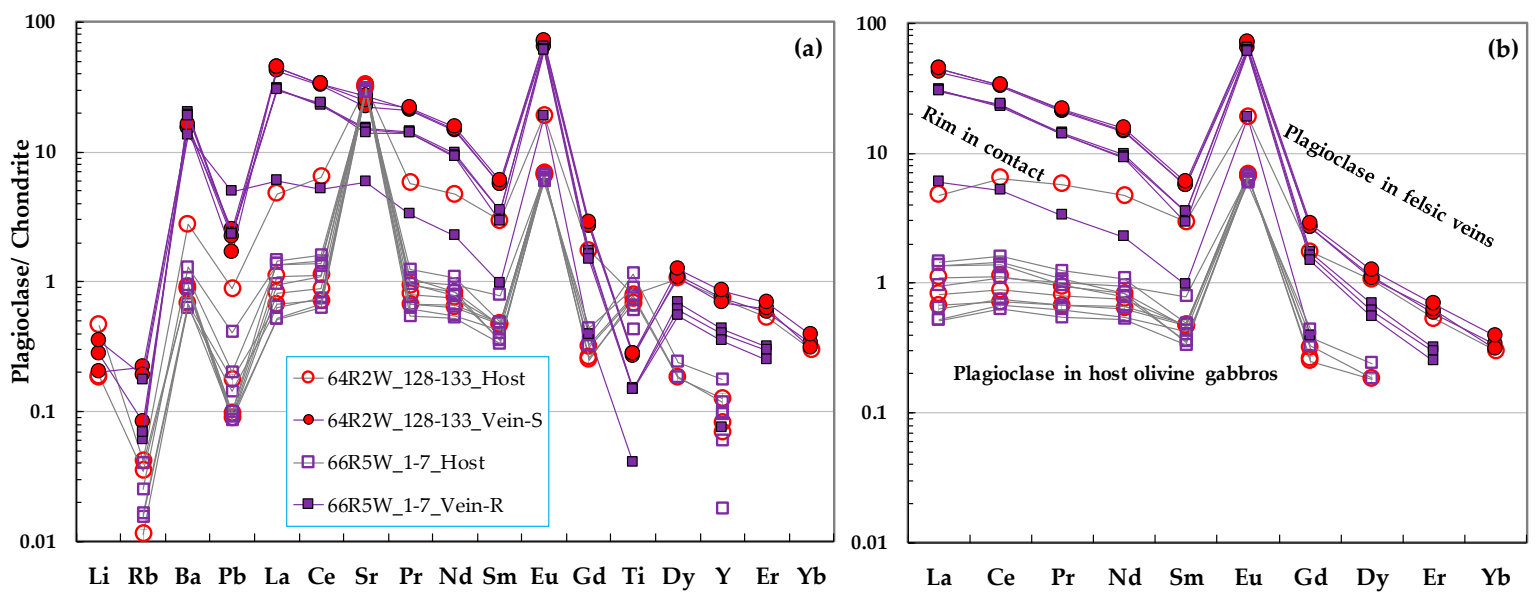

Figure 13. Chondrite-normalized trace (a) and REE (b) abundances of plagioclase in the host gabbros and felsic veins-Hole U1473A.

\subsection{Amphibole}

Amphibole in the host gabbros occurs as minor phase ( $<1$ vol.\%) in the form of thin selvages between olivine and plagioclase, micro-blebs in clinopyroxene and green-colorless one. In the felsic veins, the amphibole includes three types: (type 1) brownish-dark brown amphibole in veins (Vein-S and vein-D), (type 2) brown amphibole at the boundaries of Vein-R, and (type 3) greenish-colorless amphibole in all felsic veins.

Amphibole stoichiometry is calculated following the method proposed by Ridolphi in Reference [38]. Calculated amphibole stoichiometry is used for obtaining amphibole nomenclature after 
Locock in Reference [39] that follows the International Mineralogical Association (IMA) classification scheme [40]. All the amphiboles in studied samples are calcic amphibole, in which greenish-colorless amphiboles are actinolite while brownish-dark brown amphiboles comprise magnesio-hornblende, magnesio-ferri-hornblende, magnesio-hastingsite and Ti-rich magnesio-hastingsite. They are plotted in the field of tremolite, magnesio-hornblende, and pargasite (Figure 14).

The differences in color of the amphibole Hole U1473A can be distinguished chemically based on their $\mathrm{TiO}_{2}$ and $\mathrm{Al}_{2} \mathrm{O}_{3}$ contents. Colorless and greenish amphiboles is typified by $\mathrm{TiO}_{2}<0.5 \mathrm{wt} . \%$ and $\mathrm{Al}_{2} \mathrm{O}_{3}<3 \mathrm{wt} . \%$; for brownish amphiboles, the composition ranges from $\mathrm{TiO}_{2}=0.5-1.5 \mathrm{wt} . \%$ and $\mathrm{Al}_{2} \mathrm{O}_{3}$ $=3-6 \mathrm{wt} . \%$ whereas in dark brown varieties it is $>1.5 \mathrm{wt} . \%$ and $>6 \mathrm{wt} . \%$ of $\mathrm{TiO}_{2}$ and $\mathrm{Al}_{2} \mathrm{O}_{3}$, respectively. Many grains have cores of brown-dark brown amphibole rimmed by greenish-colorless one.

The major element variations of amphibole in felsic rocks and in the host gabbros are depicted in Figure 15. The brown amphiboles in felsic veins show positive correlations between $\mathrm{Al}_{2} \mathrm{O}_{3}$ and $\mathrm{TiO}_{2}$, $\mathrm{Na}_{2} \mathrm{O}$ contents and a negative correlation between their Mg\# (core composition ranging from 62-75) and $\mathrm{TiO}_{2}$ content and also between $\mathrm{Al}_{2} \mathrm{O}_{3}$ and $\mathrm{SiO}_{2}$ contents. Whereas, no relationship could be seen from the amphibole in the host gabbros, especially in $\mathrm{Al}_{2} \mathrm{O}_{3}$ versus $\mathrm{TiO}_{2}$ diagram (Figure $15 \mathrm{c}$ ). It is likely that the composition of amphiboles in Vein-D has narrow range of variation with lower $\mathrm{Mg \#}$ and $\mathrm{TiO}_{2}, \mathrm{Al}_{2} \mathrm{O}_{3}, \mathrm{Na}_{2} \mathrm{O}$ contents than those of other vein types.

Trace and REE patterns of amphibole in the host gabbros and felsic veins are shown in Figure 16. Trace and REE patterns of amphiboles in the host gabbros are relatively uniform and similar to those of clinopyroxene. Whereas, broader ranges of trace and REE abundances (up to more than one order of magnitude compared to those of amphibole in the host gabbros) are typical characteristic of amphiboles in the felsic veins. The brown amphiboles in Vein-D have lower trace and REE abundances but their compositions show a wider range of variation compared to those of Vein-S and Vein-R. As shown in Figure 16, the trace element patterns of amphibole Eu, Sr, and HFSE ( $\mathrm{Zr}, \mathrm{Hf}, \mathrm{Ti}, \mathrm{V})$ display various degrees of negative anomalies compared to neighboring REEs. All brown amphiboles in veins have relatively high $\mathrm{Nb}$ abundances, with $\mathrm{Nb} /$ La ratios ranging from 0.39 to 1.21.

Another interesting point is the offset lower REE abundances of green amphibole compared to brown amphibole in veins, suggesting that hydrothermal activities can modify both major and trace element compositions of the brown amphibole.

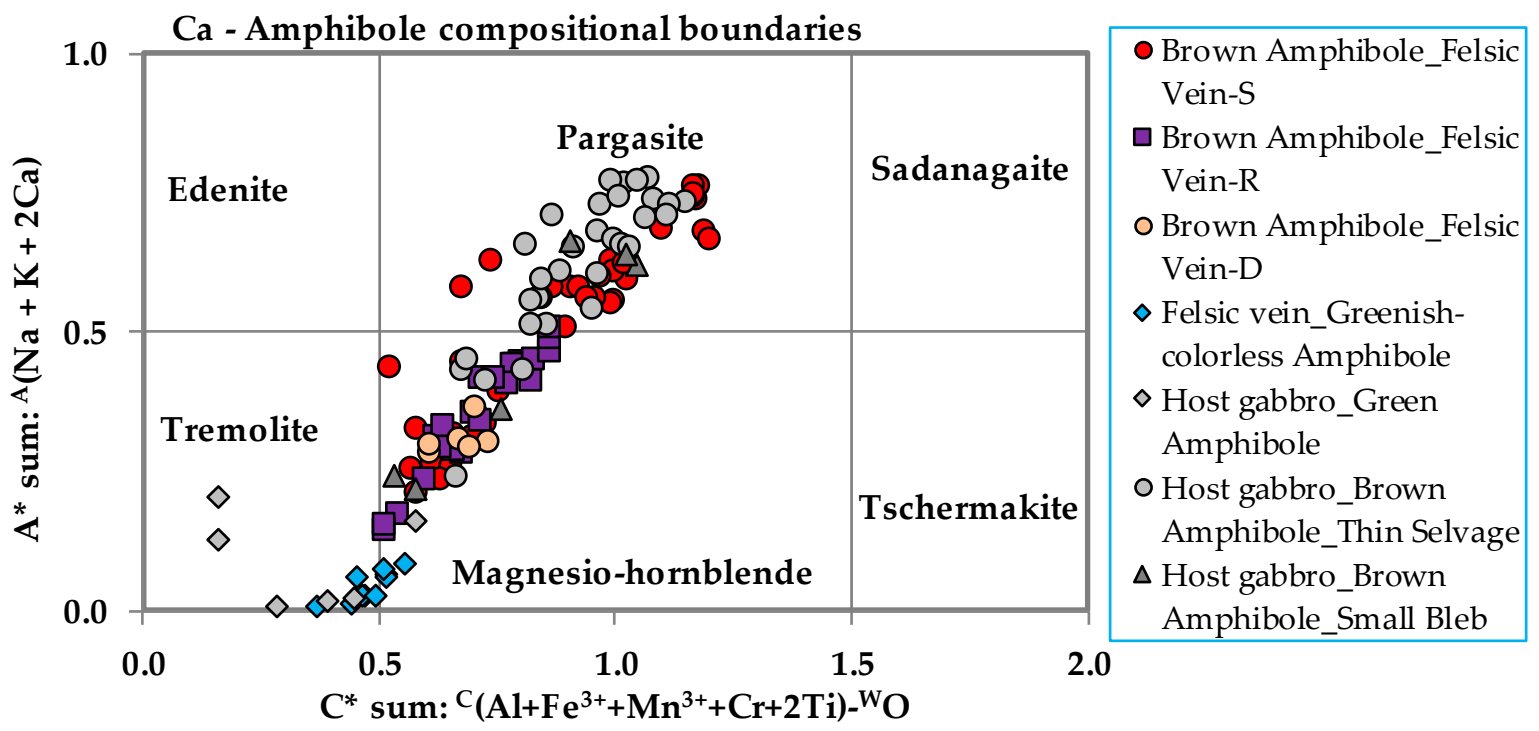

Figure 14. Nomenclature of the amphiboles-Hole U1473A. 

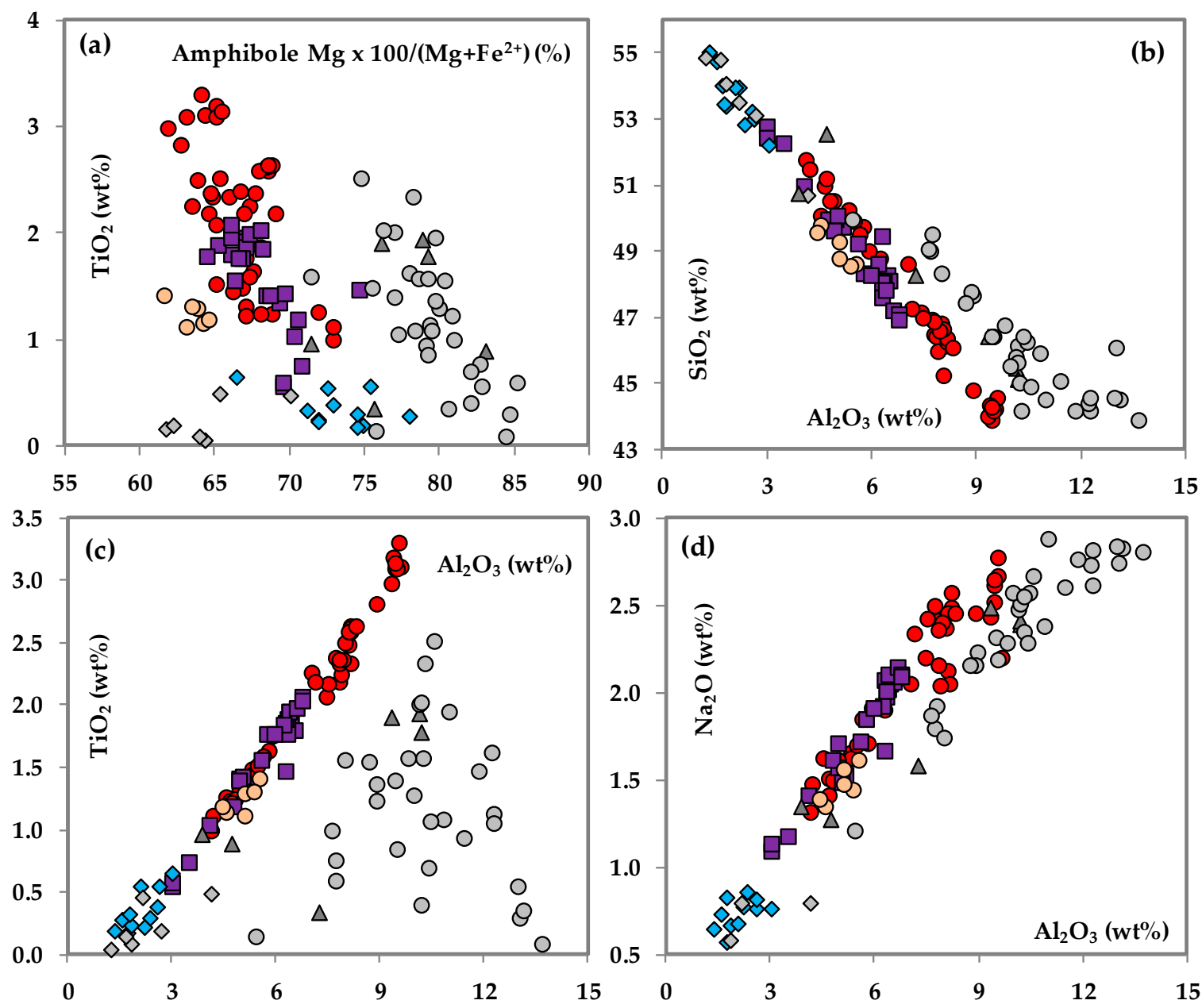

Figure 15. Major and minor element compositions of the amphiboles-Hole U1473A. (a) Amphibole $\mathrm{Mg} \#\left(100 \times \mathrm{Mg} /\left(\mathrm{Mg}+\mathrm{Fe}^{2+}\right)\right.$ versus $\mathrm{TiO}_{2}$. (b) $\mathrm{Al}_{2} \mathrm{O}_{3}$ versus $\mathrm{SiO}_{2}$. (c) $\mathrm{Al}_{2} \mathrm{O}_{3}$ versus $\mathrm{TiO}_{2}$. (d) $\mathrm{Al}_{2} \mathrm{O}_{3}$ versus $\mathrm{Na}_{2} \mathrm{O}$. Symbols are the same as those in Figure 14. Unpublished data from Du Khac Nguyen during Ph.D. course of study at Kanazawa University.

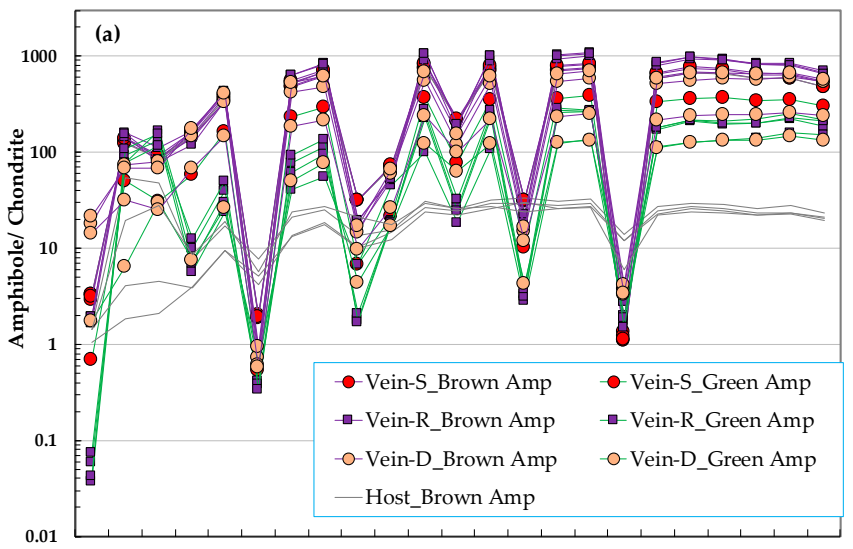

Ba Nb Ta La Ce Sr Pr Nd Zr Hf Sm Eu Gd Ti Tb Dy V Y Ho Er Tm Yb Lu

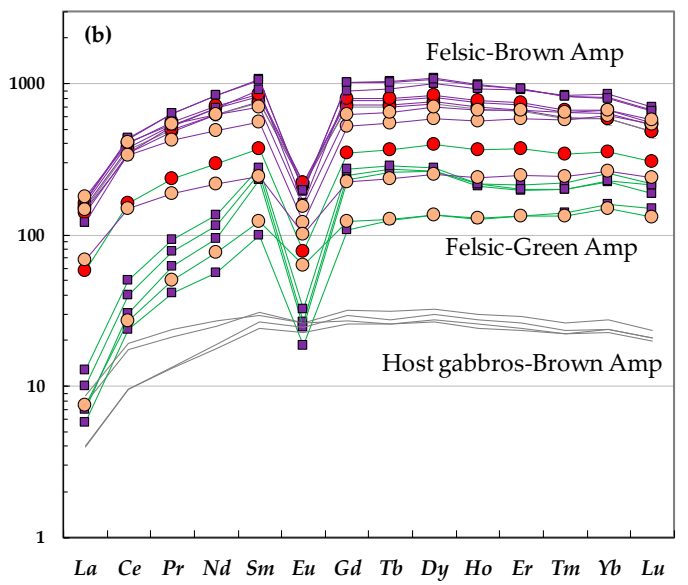

Figure 16. Chondrite-normalized trace (a) and REE (b) abundances of amphiboles in the host gabbros and felsic veins-Hole U1473A. 


\subsection{Zircon}

The zircons in felsic rocks from Hole U1473A show a relatively homogeneous major element composition in single grain from core to rim. The zircon $\mathrm{SiO}_{2}$ and $\mathrm{ZrO}_{2}$ contents in all samples vary from 32.5 to 33.6 (wt.\%) and 60.6 to 63.2 (wt.\%), respectively. To examine the REE compositions we picked up thirteen grains of zircon (2-5 grains/vein) from four samples (Vein-S: 2 samples, and Vein-R: 2 samples), of which two thin sections are described in detailed (see Section 2.2.2 and Figures 4 and 5). Total REE contents show a wide range of variation, ranging from 932-2195 ppm to 6234-11,210 ppm in Vein-S and Vein-R, respectively.

Strong positive $\mathrm{Ce}$ and weak negative Eu anomalies with steep slope pattern towards $\mathrm{Lu}$ are typical features of all the zircons analyzed in this study (Figure 17). The extent of the Ce anomaly is given by $(\mathrm{Ce} / \mathrm{Pr}) \mathrm{N}=9-60$, because of the very low La concentrations in most of the zircon (below the detection limit of LA-ICP-MS). The Eu anomaly is calculated as $\mathrm{Eu} / \mathrm{Eu}^{*}=0.16-0.41$, where $\mathrm{Eu}$ is the chondrite-normalized Eu value and $\mathrm{Eu}^{*}$ is given by Eu* $=\sqrt{ }(\mathrm{Sm} \times \mathrm{Gd}) \mathrm{N}$. The chondrite-normalized REE patterns of zircon increase rapidly from $\mathrm{Gd}$ to $\mathrm{Lu}$, and are characterized by $(\mathrm{Lu} / \mathrm{Gd}) \mathrm{N}$ ratio ranging from 19 to 32 .

The zircons in this study show the same REE patterns as those from ODP Hole 735B (Sections 3 and 4, below $500 \mathrm{mbsf}$ ). It is noteworthy that few data from Hole U1473A display various levels of REE concentrations, covering the entire variation range of those from Hole 735B. Pietranik and her colleagues in Reference [12] interpreted that these zircons were crystallized from the silica rich melts which derived by fractional crystallization of the parental mid-ocean-ridge basalt (MORB) at deeper sections of Hole 735B.

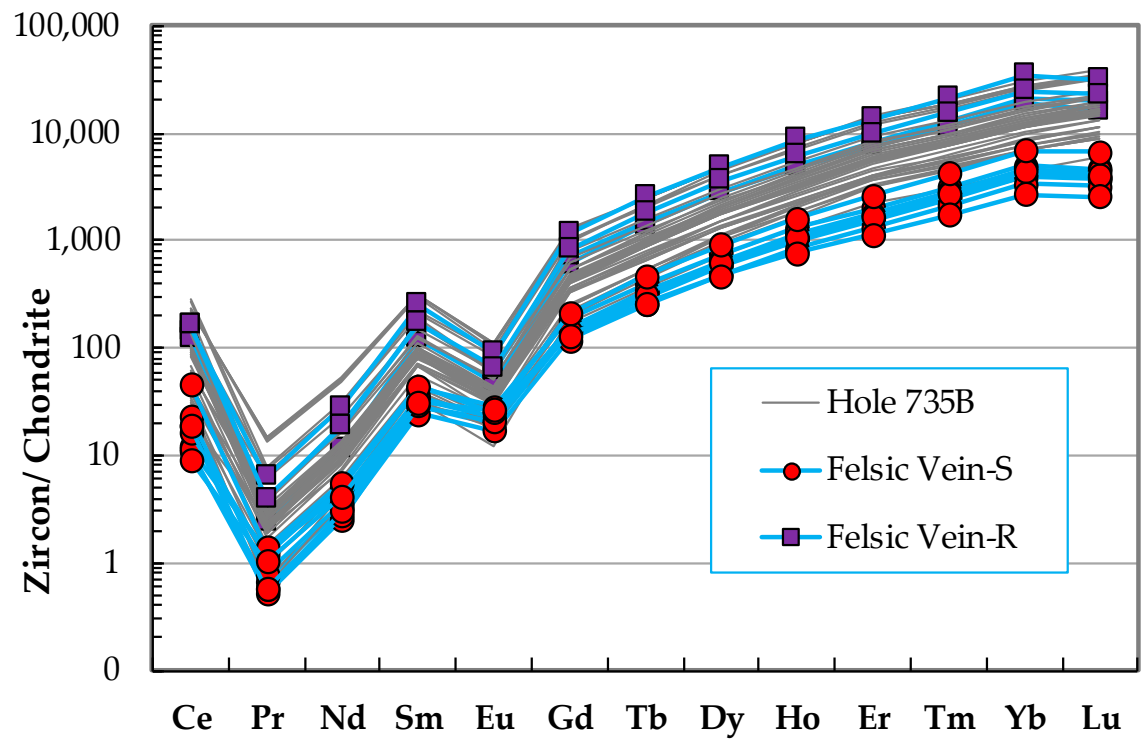

Figure 17. Chondrite-normalized rare earth element abundances of zircon in felsic veins, from IODP Hole U1473A and a comparison with those of ODP Hole 735B, Sections 3 and 4 including 42 zircon analyses; data from Reference [12]. Chondrite values are from Reference [37].

\section{Bulk Rock Estimation}

In order to estimate the effects of the felsic melts on the host gabbros and to highlight the evolved melt characteristics, we have computed whole rock composition for both host gabbros and felsic veins based on minerals chemistry and their modal proportions in thin sections. Input components of each mineral is average composition of all the analyses from the cores and the rims of the mineral in the same sample, except for the olivine in sample $41 \mathrm{R} 2,26-31 \mathrm{~cm}$. Since all of olivine grains were altered to secondary minerals, we assumed that the olivine compositions are equivalent to those of another olivine gabbro, sample 66R5, 1-7 cm. Densities of minerals were also assumed and are listed in Supplementary Table S8. Summary of bulk rock estimation of seven studied samples is given in Table 4 and Figure 18. 
Table 4. Summary estimated dry bulk rock compositions (wt.\%) of the host gabbros and felsic veins—Hole U1473A.

\begin{tabular}{|c|c|c|c|c|c|c|c|c|c|c|c|c|c|c|}
\hline \multirow{2}{*}{$\begin{array}{l}\text { Core } \\
\text { Oxide }\end{array}$} & \multicolumn{2}{|c|}{$\begin{array}{c}41 \mathrm{R} 2 \\
26-31 \mathrm{~cm}\end{array}$} & \multicolumn{2}{|c|}{$\begin{array}{c}64 \mathrm{R} 2 \\
110-113 \mathrm{~cm}\end{array}$} & \multicolumn{2}{|c|}{$\begin{array}{c}64 \mathrm{R} 2 \\
128-133 \mathrm{~cm}\end{array}$} & \multicolumn{2}{|c|}{$\begin{array}{c}66 \mathrm{R} 4, \\
46-49 \mathrm{~cm}\end{array}$} & \multicolumn{2}{|c|}{$\begin{array}{r}66 \mathrm{R} 5 \\
1-7 \mathrm{~cm}\end{array}$} & \multicolumn{2}{|c|}{$\begin{array}{c}68 \mathrm{R} 4 \\
121-124 \mathrm{~cm}\end{array}$} & \multicolumn{2}{|c|}{$\begin{array}{c}85 R 3 \\
83-90 \mathrm{~cm}\end{array}$} \\
\hline & Host & Vein-S & Host & Vein-S & Host & Vein-S & Host & Vein-R & Host & Vein-R & Host & Vein-S & Host & Vein-D \\
\hline $\mathrm{SiO}_{2}$ & 52.0 & 40.9 & 53.3 & 62.4 & 50.3 & 50.4 & 53.4 & 70.5 & 50.8 & 63.7 & 53.3 & 49.4 & 51.3 & 40.1 \\
\hline $\mathrm{Al}_{2} \mathrm{O}_{3}$ & 12.3 & 14.1 & 17.3 & 13.6 & 13.1 & 14.8 & 20.0 & 15.2 & 13.1 & 12.6 & 14.4 & 15.9 & 8.9 & 14.4 \\
\hline $\mathrm{TiO}_{2}$ & 0.3 & 4.1 & 0.3 & 2.5 & 0.2 & 5.1 & 0.2 & 0.2 & 0.3 & 0.6 & 0.2 & 2.8 & 1.9 & 7.3 \\
\hline $\mathrm{FeO}^{*}$ & 5.7 & 19.2 & 3.4 & 10.4 & 7.5 & 11.4 & 2.3 & 1.9 & 6.3 & 5.8 & 5.2 & 13.6 & 11.4 & 17.6 \\
\hline $\mathrm{MgO}$ & 11.8 & 2.1 & 6.8 & 1.3 & 13.6 & 3.6 & 5.6 & 1.9 & 13.3 & 5.8 & 11.8 & 3.2 & 8.4 & 1.4 \\
\hline $\mathrm{MnO}$ & 0.1 & 0.2 & 0.1 & 0.1 & 0.2 & 0.3 & 0.1 & 0.1 & 0.1 & 0.2 & 0.1 & 0.2 & 0.3 & 0.2 \\
\hline $\mathrm{CaO}$ & 15.5 & 8.4 & 15.7 & 3.9 & 12.9 & 5.6 & 15.1 & 3.7 & 13.9 & 5.5 & 12.5 & 7.1 & 15.2 & 9.4 \\
\hline $\mathrm{Na}_{2} \mathrm{O}$ & 2.3 & 4.5 & 3.1 & 5.2 & 2.2 & 5.2 & 3.4 & 6.4 & 2.2 & 5.5 & 2.4 & 5.6 & 2.6 & 4.9 \\
\hline $\mathrm{K}_{2} \mathrm{O}$ & - & 0.4 & - & 0.1 & - & 0.3 & - & 0.2 & - & 0.3 & - & 0.1 & 0.1 & 0.2 \\
\hline $\mathrm{P}_{2} \mathrm{O}_{5}$ & - & 2.9 & - & 0.5 & - & - & - & - & - & - & - & 2.2 & - & 4.2 \\
\hline $\mathrm{V}_{2} \mathrm{O}_{3}$ & - & 0.2 & - & - & - & 0.3 & - & - & - & - & - & - & - & 0.4 \\
\hline $\mathrm{ZrO}_{2}$ & - & 2.9 & - & - & - & 2.9 & - & - & - & - & - & - & - & - \\
\hline Total & 100 & 100 & 100 & 100 & 100 & 100 & 100 & 100 & 100 & 100 & 100 & 100 & 100 & 100 \\
\hline$\rho$ & 3.05 & 3.13 & 2.94 & 2.84 & 3.04 & 2.99 & 2.88 & 2.69 & 3.04 & 2.80 & 3.01 & 2.94 & 3.14 & 3.08 \\
\hline ASI & 0.39 & 0.61 & 0.51 & 0.86 & 0.48 & 0.78 & 0.61 & 0.87 & 0.46 & 0.65 & 0.54 & 0.72 & 0.28 & 0.57 \\
\hline $\mathrm{NBO} / \mathrm{T}$ & & 1.03 & & 0.47 & & 0.68 & & 0.28 & & 0.62 & & 0.77 & & 0.99 \\
\hline
\end{tabular}

Note: $\mathrm{FeO}^{*}$ : Total iron oxide content; Host: Host gabbros; $\rho$ : Bulk rock density. NBO: Number of non-bridging oxygens; $\mathrm{T}$ : Tetrahedrally coordinated cations, assumed T = $\mathrm{Si}+\mathrm{Al}+\mathrm{P}+\mathrm{Ti}+\mathrm{Zr}$. 

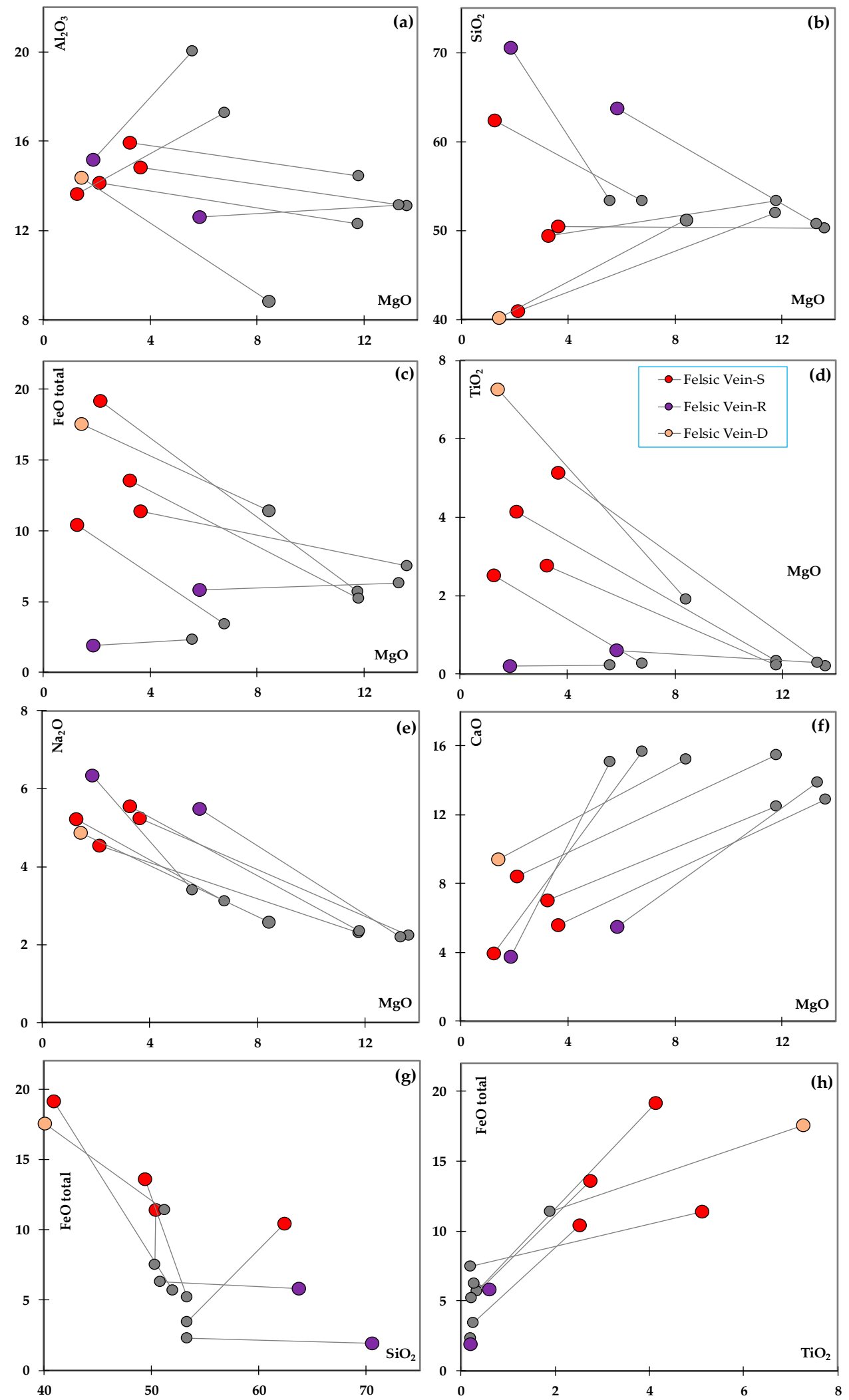

Figure 18. Variation of estimated bulk rock chemistry in wt.\% of the host gabbros and felsic veins; (a-f) $\mathrm{MgO}$ versus $\mathrm{Al}_{2} \mathrm{O}_{3}, \mathrm{SiO}_{2}, \mathrm{FeO}_{\text {total }}, \mathrm{TiO}_{2}, \mathrm{Na}_{2} \mathrm{O}$, and $\mathrm{CaO}$, respectively; (g,h) $\mathrm{SiO}_{2}$ and $\mathrm{TiO}_{2}$ versus $\mathrm{FeO}_{\text {total }}$. Gray symbols are host gabbros connected with felsic veins (colorful symbols) in the same samples by gray lines. 
Based on the calculated results, compositions of felsic vein samples have wide ranges of variation. The felsic veins have systematically lower $\mathrm{MgO}$ and $\mathrm{CaO}$ contents, but higher in $\mathrm{Na}_{2} \mathrm{O}, \mathrm{K}_{2} \mathrm{O}$ concentrations than those of the corresponding host gabbros (Figure 18a,d-f). Except for the two felsic veins formed by replacement processes, the others have much higher $\mathrm{FeO}^{*}(10.4-19.2 \mathrm{wt} . \%)$ and $\mathrm{TiO}_{2}$ (2.5-7.3 wt.\%) abundances than those of the host gabbros. Most of the veins have $\mathrm{MgO}$ content lower than $4 \mathrm{wt} . \%$ except for felsic vein sample 66R5, 1-7 cm (around $6 \mathrm{wt} . \%$ ). It is interesting to note that $\mathrm{SiO}_{2}$ content in felsic veins varies inversely with the abundances of $\mathrm{Fe}-\mathrm{Ti}$ oxides and apatite, ranging widely from 40 to $70 \mathrm{wt} . \%$ (Figure 18b,c,g,h), suggesting the late precipitation of Fe-Ti oxides in the melts. The alumina saturation index (ASI) of felsic veins varies from 0.57 to 0.87 , with molar $\left(\mathrm{Na}_{2} \mathrm{O}\right.$ $\left.+\mathrm{K}_{2} \mathrm{O}\right)<\mathrm{Al}_{2} \mathrm{O}_{3}<\left(\mathrm{CaO}+\mathrm{Na}_{2} \mathrm{O}+\mathrm{K}_{2} \mathrm{O}\right)$. On the classification scheme of granitoid rocks, following Winter in Reference [41] and references therein, all felsic rocks belong to metaluminous series.

\section{Discussion}

\subsection{Preliminary Geochemical Comparison between ODP Hole 735B and IODP Hole U1473A}

Since plagioclase and clinopyroxene are the dominant phases in most of the lithologies in Hole $\mathrm{U} 1473 \mathrm{~A}$, their compositions were compared with those of Hole 735B at the Atlantis Bank area. The results are presented in Figure 19.
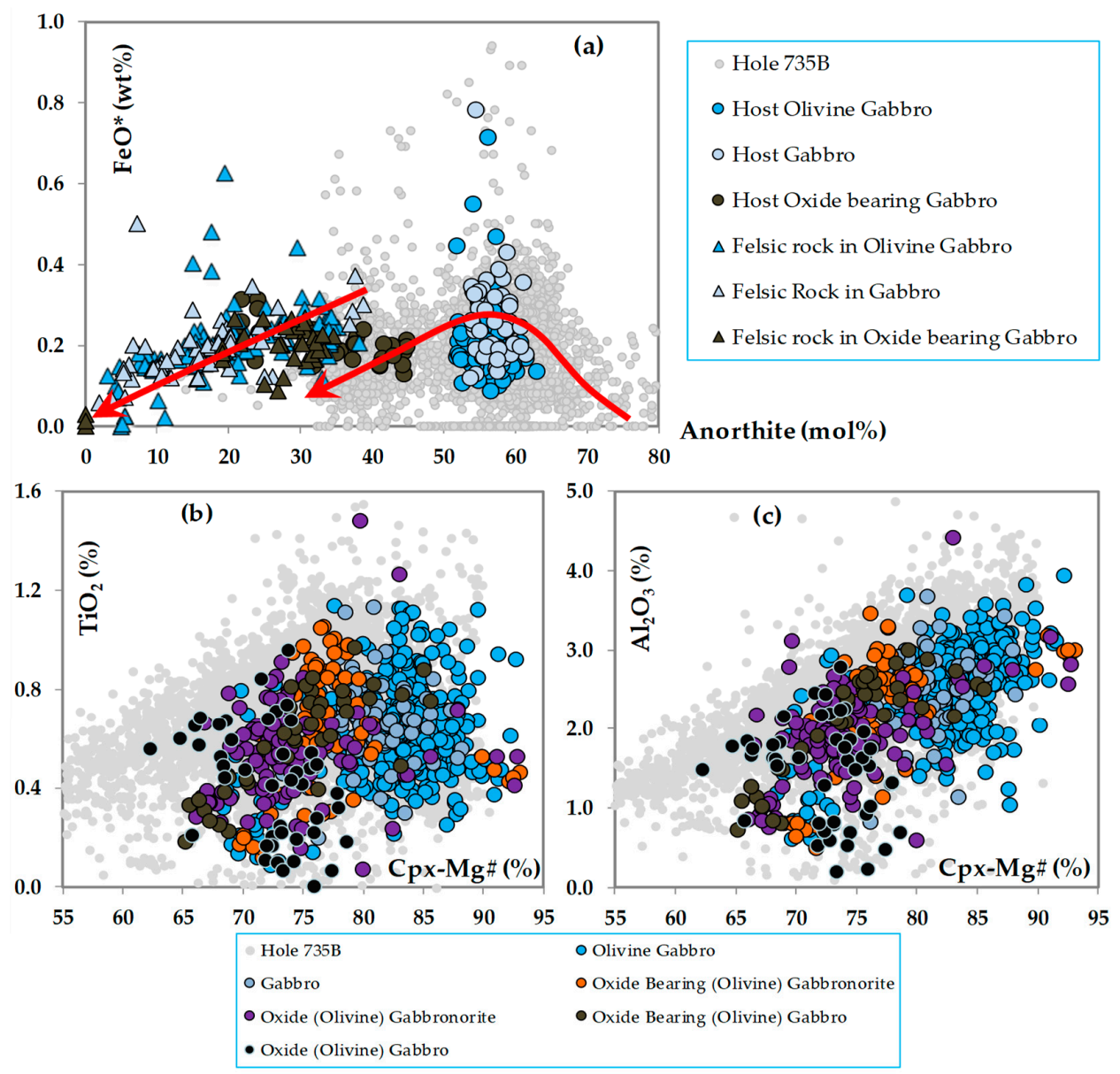

Figure 19. Preliminary geochemical comparison between IODP Hole U1473A and ODP Hole 735B, with data of ODP-Hole 735B taken from Reference [42]. (a) Plagioclase anorthite (mol.\%) versus FeO* (total iron oxide wt.\%). (b,c) Clinopyroxene $\mathrm{Mg \#} \mathrm{(mol. \% )} \mathrm{plotted} \mathrm{versus} \mathrm{TiO}_{2}$ and $\mathrm{Al}_{2} \mathrm{O}_{3}$, respectively; unpublished data from Du Khac Nguyen during Ph.D. course of study at Kanazawa University. 
Figure 19a shows the relationship between plagioclase anorthite and total iron oxide (FeO* wt.\%) contents compared with data from Hole 735B. Bimodal distribution of decreasing FeO*, which was suggested from Hole 735B (red arrows in the figure are from Reference [42]), could be observed in Hole U1473A. The first trend is recorded by the increasing FeO* from troctolite to olivine gabbro (Hole 735B), followed by a steady decrease in $\mathrm{FeO}^{*}$ content in oxide gabbro of both holes. The other trend is marked by an offset and starts from higher $\mathrm{FeO}^{*}$ content at around $\mathrm{An}_{40}$ which is associated with felsic veins. There is an overlap in the composition of plagioclase in the felsic veins and those in the oxide gabbros at around $\mathrm{An}_{30}$ to $\mathrm{An}_{40}$. The plagioclase in the felsic veins is likely to have higher $\mathrm{FeO}^{*}$ abundance than that in oxide gabbros.

The minor element ( $\mathrm{Ti}$ and $\mathrm{Al}$ ) compositions of clinopyroxene in Hole U1473A show steady decreasing trends correlated to decreasing Mg\# (Figure 19b,c), which is consistent with the results from Hole 735B. It is noteworthy that clinopyroxene in some of oxide (bearing) (olivine) gabbro(norite)s has very high $\mathrm{Mg \#} \mathrm{(up} \mathrm{to} \mathrm{around} 90$ ).

Although our data do not cover the whole geochemical ranges for the entire drilled cores from Hole U1473A, the petrological and mineral chemical characteristics of our data are almost similar and are within the ranges of those in Hole 735B as described by Dick et al. [42]. It is confirmed that the felsic rocks are observed in all of the lithologies.

\subsection{Effect of Later Hydrothermal Alteration on the Studied Felsic Rocks}

Some of the main constituents in the felsic veins can be formed by hydrothermal activities. Metasomatic amphibole may form from clinopyroxene, and quartz may also precipitate from hydrothermal fluids. Here we distinguish the origin of the studied felsic rocks, whether they are magmatic or hydrothermal.

The zircon REE patterns in four studied felsic rocks are depicted in Figure 17. The high total REE content of zircons, the steep REE pattern with gradual increasing values towards $\mathrm{Lu}$, and associated strong positive $\mathrm{Ce}$ and weak negative Eu anomalies are typical characteristics of unaltered magmatic zircon [43,44]. In addition, REE patterns of plagioclase and amphibole in the veins are similar to those of the host gabbros although their abundances are different, up to more than one order of magnitude higher in the vein minerals (Figures 13 and 16). All brown amphiboles in veins have relatively high $\mathrm{Nb}$ abundances, with $\mathrm{Nb} /$ La ratios ranging from 0.39 to 1.21. This distinguishes magmatic amphibole from hydrothermal one as discussed in detail by Coogan in [45]. Noticeably, brown amphiboles in Vein-D have lowest REE abundances, and lowest $\mathrm{Nb} / \mathrm{La}$ ratios (from 0.39 to 0.5 ) compared to those of the other vein types, suggesting that the melt forming this Vein-D was produced at the earlier stage on the liquid line of descent. Whereas, brown amphiboles in Vein- $\mathrm{R}$ have highest $\mathrm{Nb} / \mathrm{La}$ ratios (up to 1.21), refer to the most evolved melt which formed felsic vein in the studied samples. This is completely consistent with the high abundance of quartz in this vein type. It is expected that the extreme REE enrichments at various levels could only be explained by different degrees of fractional crystallization. Interaction between evolved melt and the host rock is limited at the vein boundaries by the REE enrichments at the rim of host minerals in contact with the veins (Figures 11 and 13).

Compared to brown amphiboles, green amphiboles in veins have lower trace-REE abundances (Figure 16), suggesting hydrothermal reactions from pre-existing clinopyroxene and/or brown amphibole. As shown in Figure 7a,b, clay materials such as saponite, and actinolitic green-colorless amphibole are secondary hydrothermal phases, which were formed by decomposition of the magmatic brown amphibole. These textures coupled with the presence of green amphibole with low-trace element abundances suggest that the studied felsic veins were affected by hydrothermal alteration, but the main constituents were not much modified by the hydrothermal activities. The formation of quartz in the Vein-R is discussed in detail in Section 5.4.

In summary, we emphasize that the studied felsic veins have a magmatic origin. After the formation, however, these veins might have acted as pathways for hydrothermal fluids infiltration to modify both the felsic rocks and their host gabbros. 


\subsection{Proposed Model for the Origin of Studied Felsic Veins}

There are at least three different existing models to explain the formation of $\mathrm{SiO}_{2}$-rich melts in the lower oceanic crust as summarized by Koepke et al. [14] as follows: (1) highly fractional crystallization from a parental MORB, (2) hydrous partial melting of gabbroic rocks and/or hydrothermally altered sheeted dikes, and (3) liquid immiscibility. He also pointed out that $\mathrm{TiO}_{2}, \mathrm{FeO}$, and REE concentrations are the key for distinguishing melts generated from various processes $[10,13,14]$.

It is expected that the melts produced by hydrous partial melting will have very low concentrations of $\mathrm{TiO}_{2}, \mathrm{FeO}$, and $\mathrm{REE}$ because these components are depleted in both cumulate gabbros and the hydrothermally altered rocks. This is completely in contrast with the feature of the felsic veins described in this manuscript. We do not exclude this model for the formation of other felsic rocks in the Hole U1473A and in Atlantis Bank area, however, it is unlikely that hydrous partial melting played a significant role, at least for the studied samples. On the contrary, $\mathrm{TiO}_{2}, \mathrm{FeO}$, and $\mathrm{REE}$ concentrations are significantly higher in the melts formed by fractional crystallization and/or liquid immiscibility processes. These are potential candidates for the formation of the felsic vein samples presented in this manuscript.

In order to clearly describe the variation of trace elements in felsic melt at different magmatic stages on the liquid line of descent, we reconstructed HFSE-REE patterns of the melts in equilibrium with the brown amphiboles in felsic veins (Figure 20). Since partitioning of trace elements between amphibole and melt is very complicated, depending on amphibole major element compositions, silicate melt compositions as well as pressure and temperature conditions; we applied amphibole-melt partition coefficients (Kds) from an experimental study of Klein et al. [46] on quartz-dioritic to tonalitic melts at $1 \mathrm{GPa}$, temperatures of $900-800{ }^{\circ} \mathrm{C}$. The reconstructed melt patterns are characterized by the extreme abundances of all rare earth elements at various levels, ranging from 2 to 3 log units higher than those of the chondrite with strong depletion in Eu and HFSEs, suggesting that plagioclase and zircon have already fractionated.
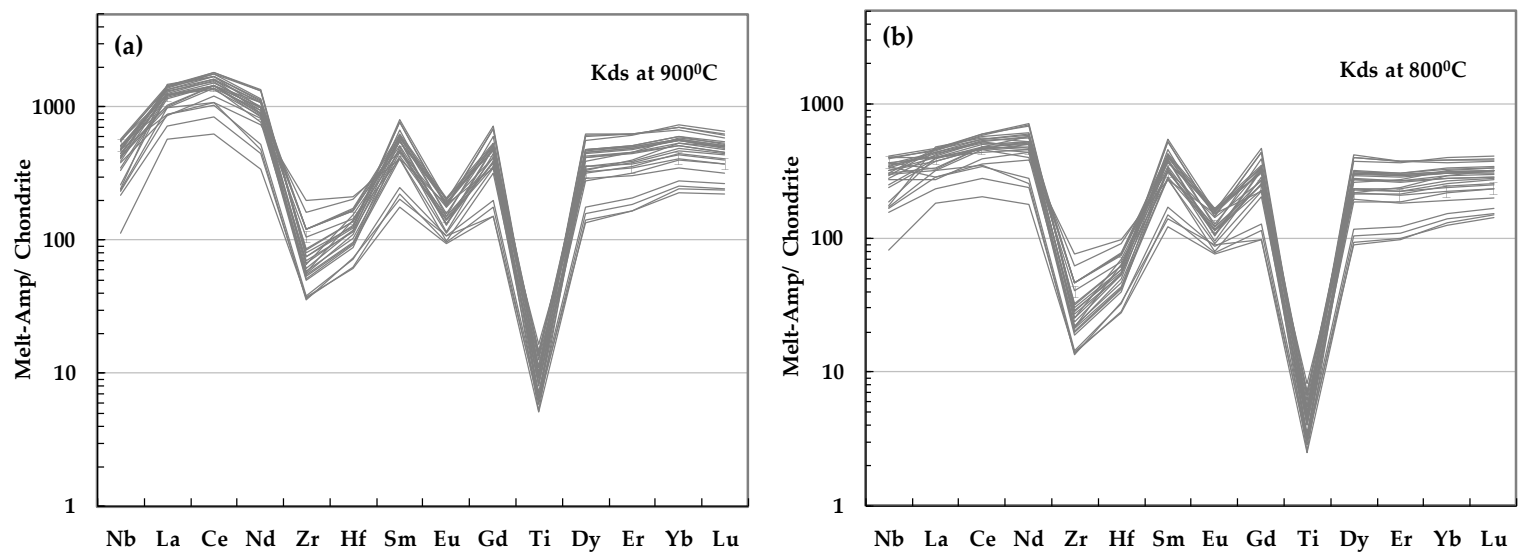

Figure 20. Reconstructed felsic melts pattern in equilibrium with brown amphibole in veins; amphibole-melt partition coefficients (Kds) from Klein et al. in Reference [46]. (a) Kds at $900{ }^{\circ} \mathrm{C}$, (b) $\mathrm{Kds}$ at $800{ }^{\circ} \mathrm{C}$. Unpublished data from Du Khac Nguyen during Ph.D. course of study at Kanazawa University.

Even after using the Ti-rich amphiboles $\left(\mathrm{TiO}_{2}\right.$ content ranges from 1 to $\left.3.5 \mathrm{wt} . \%\right)$ for this reconstruction, the deep troughs of $\mathrm{Ti}$ in reconstructed melt compositions is clearly visible. As ilmenite is the host mineral of $\mathrm{Ti}$ in the oceanic gabbros, there are three possibilities to explain for the depletion of Ti in Figure 20 as follows: (1) a large volume of ilmenite has already fractionated at earlier stages into oxide gabbros, (2) the parental melt was originally depleted in Ti compared with the abundance of REEs, and (3) a large amount of $\mathrm{TiO}_{2}$ has partitioned into a secondary melt rich in Fe-Ti oxides/liquid immiscibility. If the first case is the only model, it is difficult to explain the formation of clinopyroxene 
with very high Mg\# (up to around 90) (Figure 19b) but rich in REE in oxide gabbros (not shown here), and bulk rock estimated results (Table 4, Figure 18). It is noteworthy that only fractional crystallization cannot explain chemical characteristics of the studied felsic veins. These characteristics, high Mg\# with high trace element abundances, can be explained by interaction between the evolved felsic melts and the host gabbros, where the Mg\# of minerals are buffered by the host gabbros.

We apply a method proposed by Mysen in Reference [47] to estimate the structure of the melts (NBO/T: Number of non-bridging oxygens per tetrahedrally coordinated cations shown in Table 4) based on estimated bulk rock results, adding $2 \mathrm{wt}$ \% of $\mathrm{H}_{2} \mathrm{O}$ (minimum value in hydrous melts to stabilize brown amphibole) to the total of all samples. Calculated results show that NBO/T of the felsic melts is directly proportional to the abundances of Fe-Ti oxides and apatite in thin sections, ranging widely from 0.28-1.03. It is noted that $\mathrm{NBO} / \mathrm{T}$ increases if $\mathrm{H}_{2} \mathrm{O}$ content is higher in the melt. Interestingly, when compared with experimental results on liquid immiscibility of Charlier et al. [21], at least two felsic vein samples 41R1, 26-31 cm, and 85R3, 83-90 cm, having very high NBO/T of respective 1.03 and 0.99 have formed from $\mathrm{Fe}-\mathrm{Ti}$ oxides rich liquids. If the whole rock chemistry of the studied felsic veins represents melt compositions rather than chemical accumulation, these felsic veins might be formed from Fe-Ti oxides rich melts as the results of magma un-mixing. However, we could not find clear evidence for the presence of the two melts co-existing in equilibrium in the plutonic environment to verify the liquid immiscibility model. In order to get full understanding in the origin of felsic melts, it is necessary to study more in detail the characteristics and origin of brown amphibole, Fe-Ti oxides, apatite in oxide gabbros, and the relation to these felsic rocks that could not be done in the presenting manuscript. Based on major and trace element compositions (including REE) of minerals presented, we would like to emphasize that felsic rocks are the latest magmatic products, which formed from $\mathrm{SiO}_{2}$-rich melts derived by fractional crystallization dominated mechanisms from a parental MORB.

\subsection{The Interaction between Gabbros and Highly Evolved Melts That Formed Felsic Veins in Hole U1473A}

Felsic Vein-S is typified by the sharp boundaries in terms of both texture and chemical composition compared to the host gabbro (Figures 4, 13, 15 and 16). These characteristics suggest that the felsic rocks were crystallized in a relatively large space, which probably resulted from brittle deformation of the host gabbros, resulting in very limited interaction between the evolved melts and the host minerals in contact along the vein walls.

In the felsic Vein-R, the aggregation of quartz and Fe-bearing, Mg-rich phases presented in the felsic vein with a comparable proportion, size, and shape to that of olivine in the host gabbro (Tables 1-3; Figure 7). We thus, propose that the olivine was completely dissolved along with the re-equilibration reactions of plagioclase and clinopyroxene, ending the process by the precipitation of quartz, red Fe-bearing, and Mg-rich phases at the same position of earlier olivine. The model we propose for the formation of the felsic Vein- $\mathrm{R}$ is a process of re-equilibration between a percolating evolved silica-saturated melt and the host olivine gabbro. The replacement process which formed felsic rocks can be displayed by a schematic diagram presented in Figure 21.

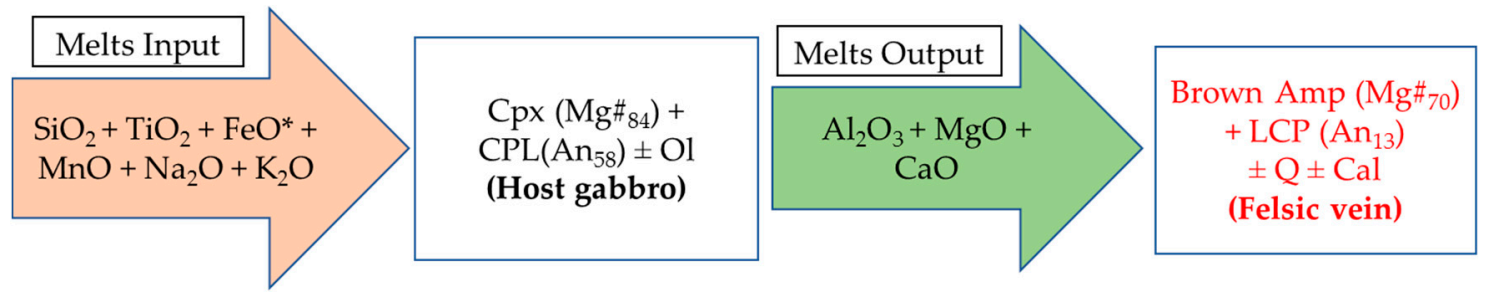

Figure 21. Schematic diagram describing felsic vein formed by replacement process. CPL: Calcic plagioclase. Cpx: Clinopyroxene. LCP: Less calcic plagioclase. Q: Quartz. Cal: Calcite. 
The melt reacting with the host gabbros is considered to be a highly-evolved melt (input melt). Addition of components such as $\mathrm{Al}_{2} \mathrm{O}_{3}, \mathrm{CaO}$, and $\mathrm{MgO}$ into the output melt can be attributed to the formation of amphibole in most of the veins. Because the replacements of plagioclase, clinopyroxene, and olivine are almost pseudomorphic, the total volume during replacement from the host gabbro to the felsic vein is nearly constant to quantify the reaction equations following mass balance method proposed by Gresens [48]. Calculations were computed using average compositions of minerals in sample 66R5, 1-7 cm. Specific gravities for minerals were assumed, using values 2.70-2.64, 3.3-3.1, and 3.4-2.62 for pairs of plagioclase $\left(\mathrm{An}_{58}\right)$-plagioclase $\left(\mathrm{An}_{13}\right)$, clinopyroxene $\left(\mathrm{Mg} \#_{84}\right)$-brown amphibole $\left(\mathrm{Mg} \#_{70}\right)$, and olivine $\left(\mathrm{Fo}_{76}\right)$-quartz, respectively. For more details, Figure 21 can be described by three specific reactions related to the main constituents of the host gabbros as follows:

(1) For plagioclase

$100 \mathrm{~g}$ plagioclase $\left(\mathrm{An}_{58}\right)+10.34 \mathrm{~g} \mathrm{SiO}_{2}+4.83 \mathrm{~g} \mathrm{Na}_{2} \mathrm{O}+0.41 \mathrm{~g} \mathrm{~K}{ }_{2} \mathrm{O} \rightarrow 97.78$ g plagioclase $\left(\mathrm{An}_{13}\right)+$ $8.37 \mathrm{~g} \mathrm{Al}_{2} \mathrm{O}_{3}+9.32 \mathrm{~g} \mathrm{CaO}$;

(2) For clinopyroxene

100 g clinopyroxene $\left(\mathrm{Mg \#}_{84}\right)+0.75 \mathrm{~g} \mathrm{TiO}_{2}+2.58 \mathrm{Al}_{2} \mathrm{O}_{3}+7.02 \mathrm{~g} \mathrm{FeO}^{*}+0.19 \mathrm{~g} \mathrm{MnO}+1.16 \mathrm{~g} \mathrm{Na}_{2} \mathrm{O}$ $+0.20 \mathrm{~g} \mathrm{~K}_{2} \mathrm{O} \rightarrow 93.94 \mathrm{~g}$ brown amphibole $\left(\mathrm{Mg \#}_{70}\right)+6.42 \mathrm{~g} \mathrm{SiO}_{2}+2.69 \mathrm{~g} \mathrm{MgO}+10.97 \mathrm{~g} \mathrm{CaO}$;

(3) For olivine

$100 \mathrm{~g}$ olivine $\left(\mathrm{Fo}_{76}\right)+38.68 \mathrm{~g} \mathrm{SiO}{ }_{2} \rightarrow 77.06 \mathrm{~g}$ quartz $+39.77 \mathrm{~g} \mathrm{MgO}+21.88 \mathrm{~g} \mathrm{FeO}+0.3 \mathrm{~g} \mathrm{MnO}$.

To evaluate the effects of melt-rock interactions, we quantify reaction between evolved melt and the host gabbro forming felsic vein (sample 66R5, 1-7 cm) by applying mass balance method one again based on estimated bulk rock composition results, using calculated bulk densities as specific gravities in the calculation. Values are 3.04-2.80 for the host olivine gabbro and felsic vein, respectively. Figure 21 can be described again by the following reaction:

(4) For olivine gabbro (sample 66R5, 1-7 cm):

100 g olivine gabbro $\left(\mathrm{SiO}_{2}=51\right.$ wt.\% $)+7.87 \mathrm{~g} \mathrm{SiO}_{2}+0.27 \mathrm{~g} \mathrm{TiO}_{2}+2.86 \mathrm{~g} \mathrm{Na}_{2} \mathrm{O}+0.27 \mathrm{~g} \mathrm{~K}_{2} \mathrm{O} \rightarrow$ $92.1 \mathrm{~g}$ felsic rock $\left(\mathrm{SiO}_{2}=64 \mathrm{wt} . \%\right)+1.52 \mathrm{~g} \mathrm{Al}_{2} \mathrm{O}_{3}+8.82 \mathrm{~g} \mathrm{CaO}+7.94 \mathrm{~g} \mathrm{MgO}+1.56 \mathrm{~g} \mathrm{FeO}$.

Although we have no clear evidence for the existence of the output melts in Figure 21, and we could not find any rock types appropriate for the output compositions in the drilled core samples, we would like to propose that the compositions of both host gabbros and migrating felsic melts are strongly modified after the reactions. These could be a potential field of study in the future to be looked at in detail.

Regarding the felsic rocks with diffused boundaries, there are two possibilities to explain their formation as follows: (1) felsic rock was formed by in situ crystallization of the interstitial evolved melt which became more enriched in apatite $\left(\mathrm{P}_{2} \mathrm{O}_{5}\right)$, zircon $(\mathrm{Zr})$, and Fe-Ti oxides components; (2) felsic melts infiltrated into the hot solidifying oxide bearing gabbro, forming network veins. In the first case, the evolved melt has very small volume compared to that in the gabbroic framework. As a result, this melt might not be able to crystallize such large volumes in the solidifying gabbros. This is completely contrary to the texture of felsic vein in the thin section (Figure 8), and thus, this model might not be the real geological situation. We would prefer to propose the second model, in which the felsic rock was produced under higher melt/rock ratios at the same time or just after the formation of the host gabbro. This is completely consistent with the diffusion models of both major, trace, and REE compositions between minerals in vein and in the host gabbro (Tables 1-3; Figures 8, 11 and 12). As the host gabbro might not be solidified yet, felsic melt could have infiltrated and reacted with the host rock extensively, forming hybridized gabbro-felsic veins. The melt forming this vein type might be produced at the earliest formation stage compared to the those melts which formed other vein types. 


\section{Summary}

The main results of this investigation can be summarized as follows:

(1) IODP-Hole U1473A was drilled on the summit of Atlantis Bank, two kilometers far from ODP-Hole 735B but the minerals composition ranges of the two holes are basically similar.

(2) Felsic rocks are the most evolved-latest magmatic crystallization products of plutonic sequences at ultraslow-spreading Southwest Indian Ridge. The melts corresponding to the felsic rocks are derived from a parental MORB by a fractional crystallization dominated mechanism. After the formation, these veins played a role as channels for hydrothermal fluids infiltration to modify both the host gabbros and felsic rocks, obscuring their magmatic origin.

(3) The relationships between felsic rocks and host gabbros of Hole U1473A are typified by the vein boundary characteristics and are strongly controlled by temperature condition of the host gabbros. Based on geochemical criteria and texture of the felsic rocks and their relationship with the host gabbros, they can be divided into three types:

(a) Felsic rocks with sharp boundaries are formed under subsolidus conditions with respect to the host gabbros. They are representatives for a crystallization fashion from highly evolved melts via relatively large cracking-fracturing systems when host rocks were already solidified and that there was very little interaction between the melt and the wall rocks.

(b) Felsic rocks formed by replacement processes are characterized by the continuity of mineral texture from the host gabbros to the felsic veins. This is referred to a pseudomorphic replacement process controlled by a dissolution-precipitation mechanism in the lower oceanic crust, in which the reactive melts are the latest quartz-saturated melts on the liquid line of descent.

(c) Felsic rocks with diffused boundaries are formed when late stage felsic melts infiltrate into framework of the host gabbros which is still hot and might not be solidified yet. In term of chronology, this vein type is formed at the earliest formation stage of $\mathrm{SiO}_{2}$-rich melts.

Supplementary Materials: The following are available online at http:/ / www.mdpi.com/2075-163X/8/12/583/ s1; Tables S1-S5: Major compositions of olivine, orthopyroxene, plagioclase, clinopyroxene, amphibole; Table S6: Major and trace element compositions of zircon. Table S7: Trace element compositions of clinopyroxene, plagioclase, and amphibole. Table S8: Average minerals compositions used for calculating bulk rock chemistry.

Author Contributions: Conceptualization and preparing manuscript, D.K.N., T.M., and B.G.; Mineral chemistry, Y.S.; LA-ICPMS analyses, A.T.; X-ray scanning image analyses, Y.H.; Core description on JR ship, T.M., B.G., L.F., C.L., J.H.N., A.S.; Leading IODP cruise, H.J.B.D., C.J.M., and P.B.

Funding: This contribution is part of Du Khac Nguyen's Ph.D. coursework at Kanazawa University with the funding provided by the Ministry of Education and Training of Vietnam (MOET) under grant number 950/QĐ-BGDĐT and Kanazawa University of Japan. This work was supported by Kanazawa University SAKIGAKE project and J-DESC post-cruise support funding.

Acknowledgments: This research used samples provided by the International Ocean Discovery Program (IODP); (for more details, see https:/ / www.iodp.org/about-iodp). We would like to thank all the scientists, as well as the captain, the crew, and the staff of the JOIDES Resolution for their efforts during Expedition 360. This work was supported by IODP Exp. 360 After Cruise Research Program, JAMSTEC, and Kanazawa University SAKIGAKE project. We also thank three anonymous reviewers whose comments and suggestions helped to improve and clarify this manuscript.

Conflicts of Interest: The authors declare no conflict of interest.

\section{References}

1. Maeda, J.; Naslund, H.R.; Jang, Y.D.; Kikawa, E.; Tajima, T.; Blackburn, W.H. High-temperature fluid migration within oceanic Layer 3 gabbros, Hole 735B, Southwest Indian Ridge: implications for the magmatic-hydrothermal transition at slow-spreading mid-ocean ridges. Proc. ODP Sci. Results 2002, 176, 56. [CrossRef]

2. Lissenberg, C.J.; MacLeod, C.J.; Howard, K.A.; Godard, M. Pervasive reactive melt migration through fast-spreading lower oceanic crust (Hess Deep, equatorial Pacific Ocean). Earth Planet Sci. Lett. 2013, 361, 436-447. [CrossRef] 
3. Lissenberg, C.J.; Dick, H.J.B. Melt-rock reaction in the lower oceanic crust and its implications for the genesis of mid-ocean ridge basalt. Earth Planet Sci. Lett. 2008, 271, 311-325. [CrossRef]

4. Lissenberg, C.J.; MacLeod, C.J. A Reactive Porous Flow Control on Mid-ocean Ridge Magmatic Evolution. J. Petrol. 2016, 57, 2195-2220. [CrossRef]

5. MacLeod, C.J.; Dick, H.J.B.; Blum, P.; Abe, N.; Blackman, D.K.; Bowles, J.A.; Cheadle, M.J.; Cho, K.; Ciazela, J.; Deans, J.R.; et al. Site U1473. Proc. IODP Sci. Results 2017, 360, 136. [CrossRef]

6. Robinson, P.T.; Erzinger, J.; Emmermann, R. The composition and origin of igneous and hydrothermal veins in the lower ocean crust; ODP Hole 735B, Southwest Indian Ridge. Proc. ODP Sci. Results 2002, 176, 66. [CrossRef]

7. Niu, Y.; Gilmore, T.; Mackie, S.M.; Bach, W. Mineral chemistry, whole-rock compositions, and petrogenesis of Leg 176 gabbros; data and discussion. Proc. ODP Sci. Results 2002, 176, 60. [CrossRef]

8. France, L.; Koepke, J.; MacLeod, C.J.; Ildefonse, B.; Godard, M.; Deloule, E. Contamination of MORB by anatexis of magma chamber roof rocks: Constraints from a geochemical study of experimental melts and associated residues. Lithos 2014, 202-203, 120-137. [CrossRef]

9. Zhang, C.; Koepke, J.; France, L.; Godard, M. Felsic Plutonic Rocks from IODP Hole 1256D, Eastern Pacific: Implications for the Nature of the Axial Melt Lens at Fast-Spreading Mid-Ocean Ridges. J. Petrol. 2017, 58, 1535-1565. [CrossRef]

10. Koepke, J.; Feig, S.; Snow, J. Late stage magmatic evolution of oceanic gabbros as a result of hydrous partial melting: Evidence from the Ocean Drilling Program (ODP) Leg 153 drilling at the Mid-Atlantic Ridge. Geochem. Geophys. Geosyst. 2005, 6, 27. [CrossRef]

11. Dick, H.J.B.; Natland, J.H.; Alt, J.C.; Bach, W.; Bideau, D.; Gee, J.S.; Haggas, S.; Hertogen, J.G.H.; Hirth, G.; Holm, P.M.; et al. A long in situ section of the lower ocean crust: results of ODP Leg 176 drilling at the Southwest Indian Ridge. Earth Planet Sci. Lett. 2000, 179, 31-51. [CrossRef]

12. Pietranik, A.; Storey, C.; Koepke, J.; Lasalle, S. Zircon record of fractionation, hydrous partial melting and thermal gradients at different depths in oceanic crust (ODP Site 735B, South-West Indian Ocean). Contrib. Mineral. Petrol. 2017, 172, 10. [CrossRef]

13. Koepke, J.; Feig, S.T.; Snow, J.; Freise, M. Petrogenesis of oceanic plagiogranites by partial melting of gabbros: an experimental study. Contrib. Mineral. Petrol. 2004, 146, 414-432. [CrossRef]

14. Koepke, J.; Berndt, J.; Feig, S.T.; Holtz, F. The formation of $\mathrm{SiO}_{2}$-rich melts within the deep oceanic crust by hydrous partial melting of gabbros. Contrib. Mineral. Petrol. 2007, 153, 67-84. [CrossRef]

15. France, L.; Koepke, J.; Ildefonse, B.; Cichy, S.B.; Deschamps, F. Hydrous partial melting in the sheeted dike complex at fast spreading ridges: experimental and natural observations. Contrib. Mineral. Petrol. 2010, 160, 683-704. [CrossRef]

16. Erdmann, M.; Fischer, L.A.; France, L.; Zhang, C.; Godard, M.; Koepke, J. Anatexis at the roof of an oceanic magma chamber at IODP Site 1256 (equatorial Pacific): An experimental study. Contrib. Mineral. Petrol. 2015, 169, 39. [CrossRef]

17. Erdmann, M.; France, L.; Fischer, L.A.; Deloule, E.; Koepke, J. Trace elements in anatectic products at the roof of mid-ocean ridge magma chambers: An experimental study. Chem. Geol. 2017, 456, 43-57. [CrossRef]

18. Natland, J.H. Magnetic susceptibility as an index of the lithology and composition of gabbros, ODP Leg 176, Hole 735B, Southwest Indian Ridge. Proc. ODP Sci. Results 2002, 176. [CrossRef]

19. Charlier, B.; Namur, O.; Grove, T.L. Compositional and kinetic controls on liquid immiscibility in ferrobasalt-rhyolite volcanic and plutonic series. Geochim. Cosmochim. Acta 2013, 113, 79-93. [CrossRef]

20. Dixon, S.; Rutherford, M.J. Plagiogranites as late-stage immiscible liquids in ophiolite and mid-ocean ridge suites: An experimental study. Earth Planet Sci. Lett. 1979, 45, 45-60. [CrossRef]

21. Charlier, B.; Grove, T.L. Experiments on liquid immiscibility along tholeiitic liquid lines of descent. Contrib. Mineral. Petrol. 2012, 164, 27-44. [CrossRef]

22. Sauter, D.; Cannat, M. The Ultraslow Spreading Southwest Indian Ridge. In Diversity Of Hydrothermal Systems On Slow Spreading Ocean Ridges, American; Geophysical Union: Washington, DC, USA, 2013; Volume 188, pp. 153-173. ISBN 978-0-87590-478-8. 
23. Dick, H.J.B.; Natland, J.H.; Miller, D.J.; Alt, J.C.; Bach, W.; Bideau, D.; Gee, J.S.; Haggas, S.; Hertogen, J.G.H.; Hirth, G.; et al. Leg 176 summary. Proc. ODP Sci. Results 1999, 176, 70. [CrossRef]

24. Casey, J.F.; Banerji, D.; Zarian, P. Leg 179 Synthesis: Geochemistry, Stratigraphy, and Structure of Gabbroic Rocks Drilled in ODP Hole 1105A, Southwest Indian Ridge. Proc. ODP Sci. Results 2007, 179. [CrossRef]

25. Dick, H.J.B.; Meyer, P.S.; Bloomer, S.; Kirby, S.; Stakes, D.; Mawer, C. Lithostratigraphic evolution of an in-situ section of oceanic layer 3. Proc. ODP Sci. Results 1991, 118. [CrossRef]

26. MacLeod, C.J.; Dick, H.J.B.; Blum, P.; Abe, N.; Blackman, D.K.; Bowles, J.A.; Cheadle, M.J.; Cho, K.; Ciazela, J.; Deans, J.R.; et al. Hole U1473A remediation operations, Expedition 362T. Proc. IODP Sci. Results 2017, 360, 11. [CrossRef]

27. Le Maitre, R.; Streckeisen, A.; Zanettin, B.; Le Bas, M.; Bonin, B.; Bateman, P. Igneous Rocks: A Classification and Glossary of Terms, 2nd ed.; Cambridge University Press: New York, NY, USA, 2002; p. 236.

28. Putnis, A. Mineral Replacement Reactions. Rev. Mineral. Geochem. 2009, 70, 87-124. [CrossRef]

29. Putnis, A. Mineral replacement reactions: From macroscopic observations to microscopic mechanisms. Mineral. Mag. 2002, 66, 689-708. [CrossRef]

30. Putnis, A.; Austrheim, H. Mechanisms of Metasomatism and Metamorphism on the Local Mineral Scale: The Role of Dissolution-Reprecipitation During Mineral Re-equilibration. In Metasomatism and the Chemical Transformation of Rock: The Role of Fluids in Terrestrial and Extraterrestrial Processes; Harlov, D.E., Austrheim, H., Eds.; Springer: Berlin/Heidelberg, Germany, 2013; pp. 141-170.

31. Putnis, A.; Putnis, C.V. The mechanism of reequilibration of solids in the presence of a fluid phase. J. Solid State Chem. 2007, 180, 1783-1786. [CrossRef]

32. Putnis, A.; John, T. Replacement Processes in the Earth's Crust. Elements 2010, 6, 159-164. [CrossRef]

33. Ruiz-Agudo, E.; Putnis, C.V.; Putnis, A. Coupled dissolution and precipitation at mineral-fluid interfaces. Chem. Geol. 2014, 383, 132-146. [CrossRef]

34. Schneider, C.A.; Rasband, W.S.; Eliceiri, K.W. NIH Image to ImageJ: 25 years of image analysis. Nat. Methods 2012, 9, 671. [CrossRef] [PubMed]

35. Droop, G.T.R. A general equation for estimating $\mathrm{Fe}^{3+}$ concentrations in ferromagnesian silicates and oxides from microprobe analyses, using stoichiometric criteria. Mineral Mag 1987, 51, 431-435. [CrossRef]

36. Morishita, T.; Ishida, Y.; Arai, S. Simultaneous determination of multiple trace element compositions in thin $(<30 \mu \mathrm{m})$ layers of BCR-2G by $193 \mathrm{~nm}$ ArF excimer laser ablation-ICP-MS: Implications for matrix effect and elemental fractionation on quantitative analysis. Geochem. J. 2005, 39, 327-340. [CrossRef]

37. McDonough, W.F.; Sun, S.s. The composition of the Earth. Chem. Geol. 1995, 120, 223-253. [CrossRef]

38. Ridolfi, F.; Zanetti, A.; Renzulli, A.; Perugini, D.; Holtz, F.; Oberti, R. AMFORM, a new mass-based model for the calculation of the unit formula of amphiboles from electron microprobe analyses. Am. Mineral. 2018, 103, 1112-1125. [CrossRef]

39. Locock, A.J. An Excel spreadsheet to classify chemical analyses of amphiboles following the IMA 2012 recommendations. Comput. Geosci. 2014, 62,1-11. [CrossRef]

40. Hawthorne, F.C.; Oberti, R.; Harlow, G.E.; Maresch, W.V.; Martin, R.F.; Schumacher, J.C.; Welch, M.D. Nomenclature of the amphibole supergroup. Am. Mineral. 2012, 97, 2031. [CrossRef]

41. Winter, J.D. Principles of Igneous and Metamorphic Petrology, 2nd ed.; Pearson Education Limited: Edinburgh Gate, UK, 2013; p. 737.

42. Dick, H.J.B.; Ozawa, K.; Meyer, P.S.; Niu, Y.; Robinson, P.T.; Constantin, M.; Herbert, R.; Natland, J.H.; Hirth, J.G.; Mackie, S.M. Primary silicate mineral chemistry of a 1.5-km section of very slow spreading lower ocean crust; ODP Hole 735B, Southwest Indian Ridge. Proc. ODP Sci. Results 2002, 176, 60. [CrossRef]

43. Hoskin, P.W.O. Trace-element composition of hydrothermal zircon and the alteration of Hadean zircon from the Jack Hills, Australia. Geochim. Cosmochim. Acta 2005, 69, 637-648. [CrossRef]

44. Fu, B.; Mernagh, T.P.; Kita, N.T.; Kemp, A.I.S.; Valley, J.W. Distinguishing magmatic zircon from hydrothermal zircon: A case study from the Gidginbung high-sulphidation $\mathrm{Au}-\mathrm{Ag}-(\mathrm{Cu})$ deposit, SE Australia. Chem. Geol. 2009, 259, 131-142. [CrossRef]

45. Coogan, L.A.; Wilson, R.N.; Gillis, K.M.; MacLeod, C.J. Near-solidus evolution of oceanic gabbros: Insights from amphibole geochemistry. Geochim. Cosmochim. Acta 2001, 65, 4339-4357. [CrossRef] 
46. Klein, M.; Stosch, H.G.; Seck, H.A. Partitioning of high field-strength and rare-earth elements between amphibole and quartz-dioritic to tonalitic melts: an experimental study. Chem. Geol. 1997, 138, 257-271. [CrossRef]

47. Mysen, B.O. The Structure of Silicate Melts. Annu. Rev. Earth Planet Sci. 1983, 11, 75-97. [CrossRef]

48. Gresens, R.L. Composition-volume relationships of metasomatism. Chem. Geol. 1967, 2, 47-65. [CrossRef]

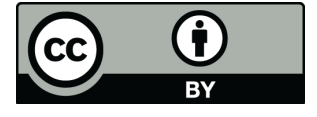

(c) 2018 by the authors. Licensee MDPI, Basel, Switzerland. This article is an open access article distributed under the terms and conditions of the Creative Commons Attribution (CC BY) license (http:/ / creativecommons.org/licenses/by/4.0/). 